
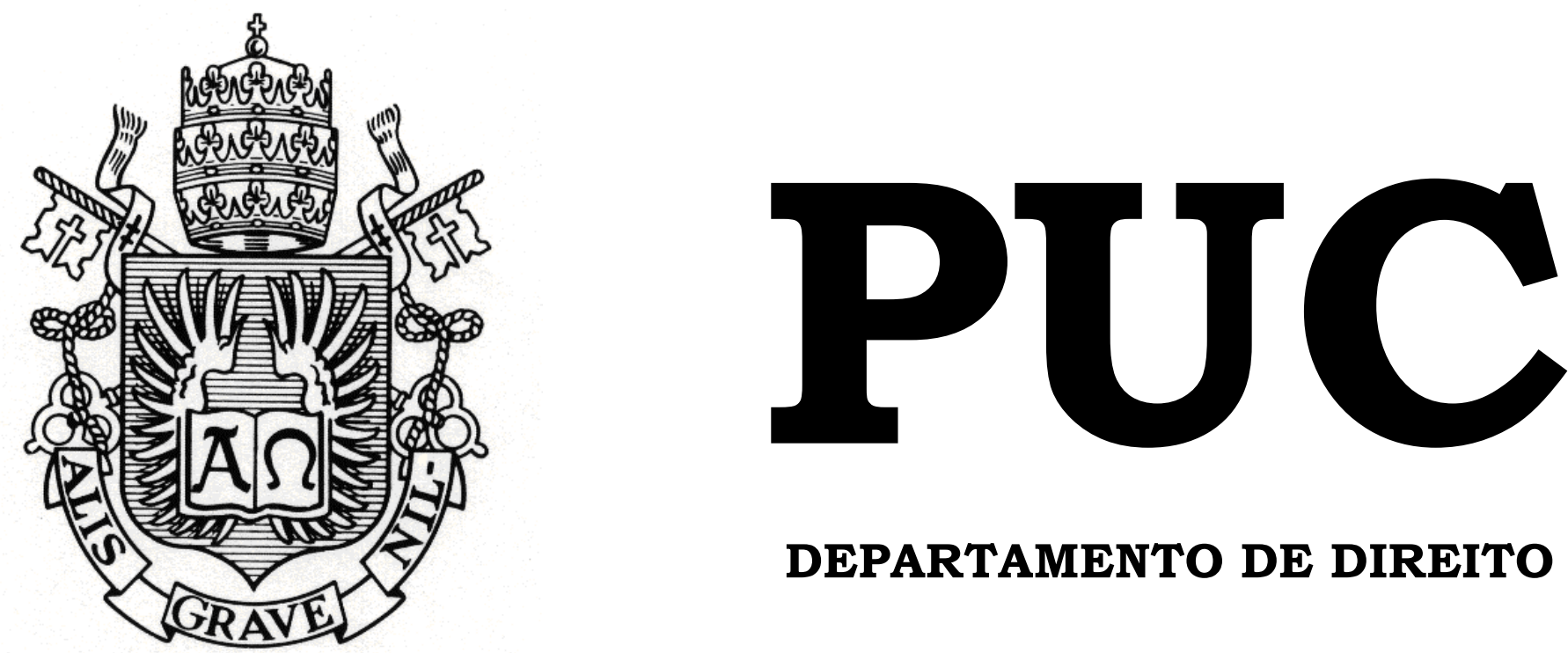

DEPARTAMENTO DE DIREITO

\title{
OS LIMITES DO DIREITO PENAL NO COMBATE À VIOLÊNCIA DOMÉSTICA NO BRASIL
}

por

MARCELA FERREIRA BALBUENA

ORIENTADORA: VICTÓRIA-AMÁLIA DE SULOCKI 2018.1

PONTIFÍCIA UNIVERSIDADE CATÓLICA DO RIO DE JANEIRO RUA MARQUÊS DE SÃO VICENTE, 225 - CEP 22453-900 RIO DE JANEIRO - BRASIL 


\title{
OS LIMITES DO DIREITO PENAL NO COMBATE À VIOLÊNCIA DOMÉSTICA NO BRASIL
}

\author{
por \\ MARCELA FERREIRA BALBUENA
}

Monografia apresentada ao Departamento de Direito da Pontifícia Universidade Católica do Rio de Janeiro (PUC-Rio) para a obtenção do Título de Bacharel em Direito.

Orientadora: Victória Amália De Barros Carvalho Gozdawa De Sulocki 


\title{
RESUMO
}

\author{
BALBUENA, Marcela Ferreira. Os Limites do Direito Penal no combate \\ à violência doméstica no Brasil. Rio de Janeiro. 2018. 77 p. Monografia de \\ final de curso. Departamento de Direito da Pontifícia Universidade Católica do \\ Rio de Janeiro - PUC-Rio.
}

A violência doméstica é apenas uma das diversas formas de expressão da violência de gênero contra a mulher. Esse problema não é recente, muito menos individual, atingindo mulheres de todas as idades e classes sociais. Foi um longo caminho até que esse fenômeno ganhasse visibilidade, uma vez que era tratado como uma questão intrafamiliar, que não merecia intervenção estatal. Muito se tem apostado na criminalização como política de reconhecimento, com base na crença de que o efeito simbólico do Direito Penal seria capaz de gerar transformações sociais. Este trabalho parte de uma análise crítica feminista para desconstruir essa ideia e demonstrar, ao final, que a utilização do sistema criminal como instrumento de emancipação feminina, principalmente dentro de uma relação familiar, pode gerar o efeito inverso, reproduzindo a histórica opressão da qual a mulher tenta se libertar.

PALAVRAS ChaVeS: Violência Doméstica. Lei Maria da Penha. Criminologia Crítica. Direito Penal. Feminismo. 


\section{SUMÁRIO}

Introdução.

Capítulo 1 - A mulher e dominação masculina

1.1. A assimetria nas representações gênero: a base da violência......8-15

1.2. O Direito penal como instrumento da dominação masculina....15-23

Capítulo 2 - O tratamento dado à violência doméstica no Brasil.... 24-46

2.1- O contexto histórico nacional .24-31

2.2. Os instrumentos internacionais no combate à violência contra a mulher. $31-34$

2.3. A Lei Maria da Penha.......................................................34-38

2.3.1. A mulher e seu direito de escolha..............................38-41

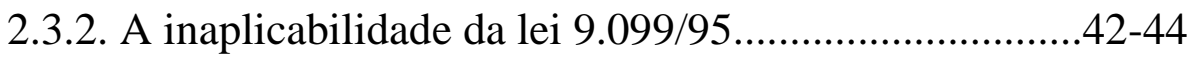

2.3.3. A efetividade da lei. $.44-46$

Capítulo 3 - O Direito Penal como instrumento de luta contra a violência

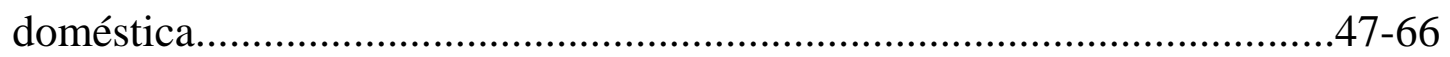

3.1. A construção de uma Criminologia Crítica...........................47-53

3.2. Direito penal mínimo $\mathrm{x}$ direito penal para as minorias............54-60

3.3. O Direito Penal como resposta à violência doméstica.............60-66

Conclusão. $.67-69$ 


\section{INTRODUÇÃO}

Este trabalho tem como objetivo propor uma reflexão acerca da viabilidade/eficiência de se apostar no sistema penal como meio idôneo para o enfrentamento da violência contra a mulher, tendo como foco particular a violência doméstica.

Durante muito tempo esse fenômeno foi naturalizado e silenciado, sendo considerado um problema intrafamiliar, de ordem privada. Era comum a reprodução de chavões como "em briga de marido e mulher ninguém mete a colher". Após muita luta, o movimento feminista conseguiu tirar a violência doméstica da invisibilidade, mostrando se tratar de um problema social, reflexo de uma histórica relação de dominação-opressão entre homens e mulheres.

Nesse contexto, foi publicada a Lei Maria da Penha, tida como uma das mais importantes vitórias na luta contra a discriminação de gênero. Representantes da criminologia crítica, porém, advertem que essa mesma lei que deveria proteger as mulheres pode estar gerando o efeito inverso, contribuindo para a perpetuação do ciclo de violência doméstica, na medida em que aposta na intervenção penal para solucionar conflitos marcados pelo vínculo afetivo entre agressor e vítima, sem se preocupar em ouvir os reais interesses e necessidades desta.

Priorizou-se, neste trabalho, os estudos de criminólogas críticas feministas, por concordar com Alda Facio quando diz que grande parte dos criminólogos críticos ao adotarem o ponto de vista das classes marginalizadas estão, na verdade, adotando o ponto de vista dos homens marginalizados, não levando em consideração as especificidades da realidade vivida pelas mulheres dentro e fora do sistema de justiça criminal. ${ }^{1}$

\footnotetext{
${ }^{1}$ FACIO, Alda; CAMACHO, Rosália. Em busca das mulheres perdidas: ou uma aproximação crítica à criminologia. In: CLADEM. Mulheres: vigiadas e castigadas. São Paulo, 1995, p. 63
} 
Como demonstram essas criminólogas, o Direito Penal sempre foi utilizado como instrumento das classes dominantes para manter e legitimar a estrutura patriarcal, caracterizada pela opressão da mulher. Desde a época da colonização, esse ramo do direito dividia as mulheres de acordo com sua reputação sexual, definindo que somente aquelas que seguissem os padrões socialmente estabelecidos mereceriam sua proteção, discurso que se mantém arraigado na justiça criminal até hoje, ainda que sob outra roupagem.

Utilizar-se de um instrumento essencialmente machista e opressor para liderar a luta de emancipação feminina mostra-se uma estratégia extremamente arriscada, mas grande parte do movimento feminista vem apostando nela. Tem-se observado nas últimas décadas uma crescente demanda pela criminalização de condutas como política de reconhecimento, como se a criminalização fosse uma fórmula mágica para resolver todos os problemas, pouco se refletindo sobre as suas reais consequências.

Assim, o que se tentará demonstrar nas próximas páginas é que reconstruir um problema privado como um problema social, não significa que se deva convertê-lo, quase que automaticamente, em um problema penal, que tem reproduzido a mesma opressão da qual as mulheres tentam se libertar.

No primeiro capítulo, serão discutidas as origens da assimetria dos papéis masculinos e femininos na sociedade, bem como o papel que o Direito Penal teve na sua legitimação. Essa primeira abordagem se mostra imprescindível para a compreensão dos processos históricos e culturais a partir dos quais se desenhou a violência doméstica nos moldes em que hoje se apresenta, o que possibilita uma reflexão mais fundamentada acerca dos possíveis remédios a serem adotados para combatê-la.

No segundo capítulo, será traçada uma análise crítica da Lei Maria da Penha no tocante ao seu caráter punitivo, demonstrando como ela retirou todo o protagonismo e autonomia da mulher na luta por sua emancipação, reproduzindo os ideais patriarcais que se pretende combater. 
Por fim, no terceiro capítulo, serão discutidos os limites e possibilidades do Direito Penal como instrumento de luta de grupos historicamente oprimidos, em especial das mulheres vítimas de violência doméstica. 


\section{A MULHER E A DOMINAÇÃO MASCULINA}

\subsection{ASSIMETRIA NAS REPRESENTAÇÕES DE GÊNERO: A BASE DA VIOLÊNCIA}

Para compreender a violência contra as mulheres, em especial aquela que ocorre dentro do seio doméstico, faz-se mister abordar, ainda que brevemente, as origens da desigualdade de poder entre homens e mulheres, bem como da crença na suposta superioridade do sexo masculino sobre o feminino. Não se pretende esgotar todas as discussões a respeito dessas questões, mas apenas tentar demonstrar que essa modalidade de violência é, na verdade, apenas uma das várias formas de expressão de um sistema de dominação-subordinação histórico, pautado na discriminação de gênero.

Simone Beauvoir mostra (1970), recorrendo aos estudos históricos de Engels sobre a origem da família, que em momentos anteriores à descoberta do fogo, o homem dependia da vontade da Natureza, estando limitado a esperar que ela se manifestasse ou se guardasse, uma vez que não conseguia controlá-la nem compreendê-la. A colheita é o exemplo utilizado pela autora: não sabendo o seu funcionamento, plantava e esperava os frutos num futuro incerto. ${ }^{2}$

A mulher, por sua vez, como Grande Mãe, possuía conhecimentos inatos sobre fertilidade e, assim, tornou-se não só a responsável pelas boas safras e pelo trabalho no campo, como também a mediadora entre o homem e o terreno, sendo reconhecida, legitimamente, como detentora de uma capacidade mística superior.

A "grande derrota histórica do sexo feminino"3, segundo Beauvoir, ocorre após a descoberta do fogo, que permitiu a criação de ferramentas a partir do

\footnotetext{
${ }^{2}$ BEAUVOIR, SiMone de. O Segundo Sexo I: fatos e mitos. São Paulo: Difusão Europeia do Livro, 1970.

${ }^{3}$ BEAUVOIR, Simone de. O Segundo Sexo II: a experiência vivida. São Paulo: Difusão Europeia do Livro, 1967, p. 74
} 
derretimento do metal. O homem não precisa mais se curvar diante da natureza; ele se torna capaz de ter o controle que antes não era possível. É nessa virada que ele se desvencilha definitivamente do império da feminilidade e passa a querer dominar a mulher, por meio do uso da força.

Com os novos instrumentos adquiridos, a agricultura estende seus domínios. Um trabalho intensivo é exigido para desbravar florestas e tornar os campos produtivos. O homem recorre, então, ao serviço de outros homens que reduz à escravidão, uma vez que "não somente tem força para se afirmar contra a natureza, mas também contra seus companheiros" ${ }^{4}{ }^{4}$ A propriedade privada aparece: senhor dos escravos e da terra, o homem se vê também como proprietário da mulher ${ }^{5}$, que passa a ser mantida no espaço doméstico, com sua sexualidade restrita à reprodução. Enquanto isso, o homem domina o espaço público, local onde acontecem as decisões políticas e as produções culturais.

Nesse contexto, ele se torna o detentor do poder político e social e, através de seus discursos, busca legitimar a manutenção dessa estrutura patriarcal. Para tanto, difunde a ideia de um determinismo biológico, segundo o qual as diferenças genéticas e anatômicas existentes nos corpos masculinos e femininos indicariam as funções naturais e imutáveis a que os mesmos estariam destinados.

Dentro dessa visão, o indivíduo do sexo masculino seria naturalmente racional/ativo/forte/potente/viril/possuidor, ao passo que o indivíduo do sexo feminino, seria uma criatura emocional / passiva / frágil/ impotente / pacífica /possuída. Entra também em questão a divisão sexual do trabalho, onde a mulher, por sua capacidade reprodutiva, seria, naturalmente, a responsável pelo cuidado do lar e dos filhos, enquanto o homem - provedor - seria o responsável pelo sustento da família, exercendo trabalhos externos.

\footnotetext{
${ }^{4}$ MITCHEL, Juliet. Mulheres: a revolução mais longa. In: Revista Civilização Brasileira, ano III, n. 14, 1967, p.13-15

${ }^{5}$ BEAUVOIR, Simone de. Op. Cit., p. 74
} 
Essas ideias foram reproduzidas em todas as instituições sociais (família, escola, Estado, Igreja, meio acadêmico, mercado de trabalho, etc), até impregnarem o inconsciente coletivo. ${ }^{6}$ A consequência disso foi a legitimação da subordinação feminina como algo natural, excluindo-se, as mulheres da condição de titulares de direitos e de sujeitos ativos na formação e transformação da sociedade.

A partir do século XX, porém, esse pensamento passa a ser desconstruído por teóricas feministas, que buscavam a desnaturalização das diferenças entre os sexos, sugerindo que o cerne da assimetria na representação dos papéis do homem e da mulher na sociedade seria, na verdade, o culturalismo. Assim, enquanto a natureza teria determinado as diferenças inatas dos corpos, a cultura seria responsável pela artificial atribuição de papéis e posições sociais femininas ou masculinas, criando as discriminações de gênero.

O termo "gênero" emerge, então, como um aprendizado, fruto de uma construção social, material e simbólica do que se entende por homem ou mulher, e, consequentemente, das funções sociais que se atribuem a um ou outro sexo. A mulher, assim como o homem, não se define apenas pela genética, hormônios ou atributos corporais, mas pela maneira que assume o corpo e a sua relação com o mundo.

É com base nessa ideia que Beauvoir postula a famosa frase "Ninguém nasce mulher, torna-se mulher" ${ }^{\prime 7}$. Compreender as distinções entre homens e mulheres significa compreender o processo de formação da posição masculina e feminina na sociedade, e de que forma estabelecem-se as relações de poder entre elas, desvinculando-se da ideia de que as diferenças são determinadas de acordo com uma natureza intrínseca ao sexo.

6 De acordo com Bruna FRANCHETO, "a justaposição linguística, que reúne numa só palavra homem - dois significados distintos: homem enquanto humanidade e homem enquanto ser humano do gênero masculino, demonstra o enraizamento e a cristalização cultural desse ocultamento feminino(...)". FRANCHETO, Bruna et al. Antropologia e Feminismo: Perspectivas Antropológicas da Mulher. Rio de Janeiro: Zahar, vol.1, nº 1, 1981, p.16

${ }^{7}$ BEAUVOIR, Simone de. O Segundo Sexo II: a experiência vivida. São Paulo: Difusão Europeia do Livro, 1967, p. 9. 
Nesse sentido, Juliet Mitchell aponta que o papel feminino na reprodução e na formação do núcleo familiar foi de extrema relevância para a definição dos papéis sociais, pois a maternidade é um fator biológico, universal e atemporal, que exige afastamentos periódicos do trabalho. Contudo, a administração doméstica e a socialização das crianças como sendo de responsabilidade da mulher é uma construção social, pois não há razão inerente para que a mãe biológica seja a socializadora da criança. Embora o processo de socialização seja invariável, a pessoa do socializador pode variar. ${ }^{8}$

Com efeito, a subordinação da mulher, marcada pelas suas funções domésticas e pelo controle de sua sexualidade, não resultou de um dado biológico, mas sim de toda uma cultura construída com base na ideia da fragilidade feminina e da sua vocação para a formação da família. ${ }^{9}$

Buscando desmistificar essa suposta fragilidade como algo natural, Beauvoir relata a educação das meninas para se tornarem mulheres, ou melhor, moças bemcomportadas. Desde a imposição do uso de vestidos e de brinquedos ditos "femininos" como bonecas e casinhas, até à postura, o modo de sentar e a obediência são disposições para que se tornem a mulher que estão destinadas a ser.

Pierre Bourdieu nomeia esse dever ser feminino como uma violência simbólica, na medida que ela inscreve um habitus ao corpo da mulher, com fins de produção e reprodução da cultura masculina imposta pela sociedade. ${ }^{10} \mathrm{~A}$ determinação e observação constante dos atos femininos conspiram para criar mulheres dóceis, amáveis, sensuais, delicadas, comportadas, submissas, disciplinadas, cuidadosas e sentimentais, pois essas são as características que os homens desejam

\footnotetext{
8 MITCHEL, Juliet. Mulheres: a revolução mais longa. In: Revista Civilização Brasileira, ano III, n. 14,1967, p.13-15

${ }^{9}$ Nesse contexto, a contracepção, inventada como técnica racional apenas no século XIX, constituiu uma inovação de importância histórica mundial, pois permitiu que o modo de reprodução pudesse ser transformado, ou seja, a maternidade deixou de ser a única ou a última vocação da mulher, para se tornar uma opção entre outras.

${ }^{10}$ BOURDIEU, Pierre. A Dominação Masculina. Rio de Janeiro: Bertrand Brasil, 2003.
} 
que elas possuam, uma vez que, assim, é mais fácil mantê-las sob seu domínio. As mulheres que fogem desse padrão sofrem represálias em todas as instâncias sociais.

\section{O autor continua:}

A dominação masculina, que constitui as mulheres como objetos simbólicos, cujo ser (esse) é um ser-percebido (percipi), tem por efeito colocá-las em permanente estado de insegurança corporal, ou melhor, de dependência simbólica: elas existem primeiro pelo, e para, o olhar dos outros, ou seja, enquanto objetos receptivos, atraentes, disponíveis. Delas se esperam que sejam "femininas", isto é, sorridentes, simpáticas, atenciosas, submissas, discretas, contidas ou até mesmo apagadas. E a pretensa "feminilidade" muitas vezes não é mais que uma forma de aquiescência em relação às expectativas masculinas, reais ou supostas, principalmente em termos de engrandecimento do ego. Em consequência, a dependência em relação aos outros (e não só aos homens) tende a se tornar constitutiva de seu ser. ${ }^{11}$

Não há dúvidas de que, a partir da superação do paradigma biológico pelo paradigma do gênero, o movimento feminista ${ }^{12}$ conquistou importantes avanços no tocante à emancipação feminina, uma vez que as mulheres começaram a perceber que se a distinção de gênero resulta de uma construção social, transformações nesse processo de construção podem subverter a ordem e determinar o equilíbrio entre homens e mulheres. Ainda assim, até hoje, incidem sobre elas mecanismos de controle formal e informal, que têm por escopo mantê-las no espaço privado, exercendo os papéis que lhe foram atribuídos socialmente. ${ }^{13}$

Como explica Elena Larrauri, no ambiente externo, há o que se chama de "controle público difuso", caracterizado por toda sorte de obstáculos impostos à mulher para dificultar seu acesso ao domínio público. Em toda e qualquer situação em que a mulher tente avançar para fora do espaço doméstico, haverá sempre quem lhe acuse de estar invadindo um lugar que não lhe é próprio e a mande de volta para casa. Seja pela desvalorização de sua capacidade, pela ameaça constante e velada da violência sexual, ou pelo medo de manchar sua reputação - a qual é

\footnotetext{
${ }^{11}$ BOURDIEU, Pierre. A Dominação Masculina. Rio de Janeiro: Bertrand Brasil, 2003p. 82.

${ }^{12}$ É importante destacar que embora se diga "movimento feminista", não é possível falar de um único feminismo, pois as mulheres não formam um grupo homogêneo. Cada escritora feminista apresenta uma abordagem influenciada pelo seu histórico de vida, sua formação, sua raça, sua ideologia e sua classe social.

${ }^{13}$ LARRAURI, Elena. Por qué las mujerres maltratadas retiran las denuncias? In: Mujeres y sistema penal: violencia domenstica. Montevideo: B de F Editorial, 2008, p. 95
} 
fundamentalmente definida pelos homens em função de seu comportamento sexual -, a mulher sente-se constantemente controlada em seu meio social.

O controle continua no ambiente laboral, onde enfrenta uma maior dificuldade para obter vagas, recebe salários inferiores ao dos homens e, normalmente, encara uma dupla jornada de trabalho, uma vez que permanece responsável pela manutenção da casa. Não bastassem as discriminações sofridas, muitas ainda são vítimas de assédio sexual, que em maior ou menor medida determina restrições em seu comportamento, causa transtornos psicológicos e danos à carreira.

Por fim, há o controle do qual se dedica este trabalho, que é o controle exercido dentro do próprio lar. Por vezes, ele aparece de forma sutil, como na diferença de educação concedida à menina, que, em geral, deve responder a regras muito mais rígidas em relação aos horários, atividades, companhias e experiências sexuais, ou que, na fase adulta, não tem sua voz ouvida pelo marido/companheiro, em uma verdadeira atualização da situação vivida pela mulher brasileira do século XIX, descrita com precisão por Gilberto Freyre:

Da mulher-esposa, quando vivo ou ativo o marido, não se queria ouvir a voz na sala, entre conversas de homem, a não ser pedindo vestido novo, cantando modinha, rezando pelos homens; quase nunca aconselhando ou sugerindo o que quer que fosse de menos doméstico, de menos gracioso, de menos gentil; quase nunca metendo-se em assuntos de homem. ${ }^{14}$

Em muitos casos, porém, esse controle pode tomar outras proporções. O recurso à violência, em geral, ocorre ante duas justificativas subjetivas que se fundem: (i) como ferramenta de socialização e prática educativa e (ii) como meio de manter o poder na dinâmica relacional ou de prevenir sua perda quando a mulher ameaça deixar de cumprir seu papel social. ${ }^{15}$

O receio pela perda do poder mobilizaria, assim, atitudes agressivas, que visam a manter o padrão de assimetria. De acordo com Sônia Maria de Araújo Couto,

\footnotetext{
${ }^{14}$ FREYRE, Gilberto. Sobrados e mucambos - decadência do patriarcado rural e desenvolvimento urbano.In: Intérpretes do Brasil. Rio de Janeiro: Nova Aguillar, 2 ed., 2002, p.819.

${ }^{15}$ SCHRAIBER, Lilia. Violência vivida: a dor que não tem nome. Interface - Comunicação, Saúde e Educação, Botucatu, v. 7, n. 12, p. 42, fev. 2003. Disponível em: $\langle$ http://www.scielo.br/scielo.php?script=sci_ $\quad$ arttext\&pid=S1414-32832003000100004\&lng=en\&nrm=iso>.
} 
"ao se sentir ameaçado com a perda do poder, [o homem] reage com violência, supondo ter o direito de submeter a mulher à condição de escravidão, ou de ser seu dever a 'educação' da mulher através dos métodos corretivos e violentos". ${ }^{16}$

É importante perceber que permanece bastante aceito na sociedade o discurso masculino de que a violência somente ocorre em situações nas quais há "provocação feminina" ("ela me fez perder a cabeça"), não se problematizando o uso da violência como forma padrão de reagir aos conflitos e solucioná-los, uma vez que agressividade masculina seria incontrolável, já que intuitiva e parte inseparável de seu ser. ${ }^{17}$

Por essa perspectiva, caberia à mulher se portar de forma a não provocar a perda de controle do homem, o que implica na sua anulação como sujeito. Essa culpabilização feminina apresenta-se como um dos mais perversos e funcionais mecanismos da violência de gênero, uma vez que tira o foco das raízes culturais da assimetria de poder e o coloca sobre as próprias vítimas, que, muitas vezes, sentem vergonha de admitir publicamente que sofrem agressões.

A consequência disso é a instalação do chamado ciclo da violência doméstica, que consiste na rotinização das agressões, intercaladas com períodos pacíficos entre as partes, nos quais o homem promete que não voltará a agredir. ${ }^{18}$

Conforme assevera Barroso Filho, ${ }^{19}$ nos casos de violência doméstica praticada pelo marido/companheiro, a primeira violência, em geral, não ocorre nos momentos iniciais de contatos do casal, sendo precedida pela consolidação de um vínculo de confiança. A agressão rompe de maneira drástica com essa base e, sem compreender a violência sofrida, a mulher tende a recorrer a dois mecanismos para

${ }^{16}$ COUTO, Sônia Maria de Araújo. Violência Doméstica: uma Nova Intervenção Terapêutica. Belo Horizonte: Autentica, 2005 p. 26.

${ }^{17}$ COUTO, Maria Cláudia Girotto. Lei Maria da Penha e Princípio da Subsidiariedade. São Paulo. 2016. Dissertação de mestrado defendida na USP, p. 36-37.

${ }_{18}$ TELES, Maria Amélia de Almeida; MELO, Mônica de. O que é violência contra a mulher. São Paulo: Brasiliense, 2002. p. 19

${ }^{19}$ FILHO, José Barroso. O perverso ciclo da violência doméstica contra a mulher... Afronta a dignidade de todos nós. Portal do Conselho Nacional de Justiça. Disponível em: <http://www.cnj.jus.br/atos-administrativos/atos-secretaria-geral/433-informacoes- 
elucidar o motivo dessa conduta, quais sejam: (i) a culpabilização, já que a falta de justificativas plausíveis para a violência a leva a considerar que esta só pode ter ocorrido por uma provocação sua; (ii) a busca por fatores externos ao relacionamento do casal que possam minimamente explicar ou justificar os comportamentos agressivos do parceiro, tais como a ocorrência de aborrecimentos no trabalho que o tenham deixado irritado ou então o uso de drogas ou bebidas alcoólicas.

Como explica Maria Cláudia Girotto do Couto ${ }^{20}$,

estando no bojo de um relacionamento afetivo ou já inserta em uma família constituída, é difícil que a mulher se veja como vítima de uma assimetria de poder que muitas vezes sequer é racionalizada pelos próprios parceiros. Nesse contexto, o recurso a elementos alheios à própria determinação do parceiro em agir de maneira violenta soa como um conforto e um meio de tranquilizar a psique da mulher: ela passa a considerar que, na ausência dos fatores facilitadores da violência (álcool, aborrecimentos no trabalho e sua própria "provocação"), o homem voltará a ser o parceiro pacífico que sempre foi e que compõe sua idealização.

A manutenção da mulher nesse ciclo de violência a coloca em um permanente risco de sofrer agressões, além de minar cada vez mais sua compreensão de si como sujeito autônomo. Reitere-se, porém, que a sua vulnerabilidade no que tange à violência não é uma característica ontológica, mas sim resultado de uma opressão de gênero, que pode - e deve - ser desconstruída. Empoderando-se a mulher, esta encontrará forças para romper esse ciclo.

\subsection{O DIREITO PENAL COMO INSTRUMENTO DA DOMÍNAÇÃO MASCULINA}

Ultrapassada a questão acerca das possíveis origens da assimetria das representações de gênero, passa-se a analisar o papel que o Direito Penal teve na manutenção e legitimação da mesma.

para/imprensa/artigos/13325-o-perverso-ciclo-da-violia-domica-contra-a-mulher-afronta-a-dignidadede-todos-n>. Acesso em: 20 maio 2018.

${ }^{20}$ COUTO, Maria Cláudia Girotto. Lei Maria da Penha e Princípio da Subsidiariedade. São Paulo. 2016. Dissertação de mestrado defendida na USP, p. 38 
Historicamente, a grande preocupação do Direito, no Brasil, era limitar a mulher na sua capacidade cível, no seu poder patrimonial, na sua educação e, de forma geral, no seu poder de decisão. Essa limitação cabia ao Direito Civil. Já para o Direito Penal, a preocupação era mínima, pois as mulheres, em regra, costumavam ocupar apenas o polo passivo dos delitos. ${ }^{21}$

A baixa criminalidade feminina passou a ser objeto de interesse dos criminólogos já no século XIX. Assim, em 1892, Césare Lombroso - tido como o pai da criminologia positivista ${ }^{22}$ - e Giovanni Ferrero publicaram o livro La donna delinquente ("A mulher delinquente"), onde buscavam explicar as causas desse fenômeno a partir de características físicas, biológicas e psíquicas da mulher.

Os autores sustentavam que as mulheres cometiam menos crimes porque tinham uma menor pré-disposição para a prática de condutas ousadas ou transgressoras, em razão da imobilidade de seu óvulo, e porque a responsabilidade com a vida doméstica e com o cuidado da família deixavam-nas menos expostas às diversas condições de tempo e espaço e, portanto, menos sujeitas a transformações e deformações degenerativas, que causavam o comportamento criminoso.

Dessa forma, as mulheres foram concebidas como naturalmente incapacitadas para o crime. Ao mesmo tempo, os autores alertavam que elas eram "potencialmente amorais: isto é, enganadoras, frias, calculistas, sedutoras e malévolas”. Estas, em geral, não se tornariam criminosas, mas sim prostitutas. A sexualidade mais ativa passa a ser considerada, então, a principal característica indicativa do desvio feminino.

\footnotetext{
${ }^{21}$ MONTENEGRO, Marília. Lei Maria da Penha: uma análise criminológico-crítica. Rio de Janeiro: Revan, 2015, $1^{\text {a }}$ ed. p. 33

$22 \mathrm{Na}$ criminologia positivista, estudava-se o próprio delinquente, buscando nele as causas supostamente naturais para seu comportamento desviante. Entendia-se que a etiologia do crime era essencialmente individual, sem qualquer relação com as condições sociais e contextuais nas quais o indivíduo estivesse inserido. Uma vez identificadas as características físicas, biológicas e psíquicas determinantes para a delinquência, seria possível encontrar remédios para combatê-la. O principal livro de Lombroso foi L'uomo delinquente ("O homem delinquente"), onde descreveu o criminoso nato , que segundo o autor, seria um homem atávico, degenerado, marcado pela transmissão hereditária do mal, e que, portanto, já nasceria com uma pré-disposição ao crime. Ele sustentou, ainda, que esse indivíduo poderia ser identificado por meio da observação de suas características fenotípicas.
} 
Embora esses discursos deterministas já tenham sido desconstruídos com o avanço dos estudos da criminologia crítica - tema que será analisado no terceiro capítulo -, fato é, que a sexualidade da mulher sempre foi um fator determinante para definir sua moral, o que se refletiu tanto na esfera do poder legislativo quanto do poder judiciário. Um exemplo que demonstra isso de forma muito clara é o tratamento dado à mulher vítima de crimes sexuais, ao longo da história da legislação penal brasileira.

O Código Penal de 1890 assim se pronunciava acerca do crime de estupro:

Art. 268. Estuprar mulher virgem ou não, mas honesta:

Pena - de prisão cellular por um a sei annos.

$\S 1^{\circ} \mathrm{Si}$ a estuprada for mulher publica ou prostituta:

Pena - de prisão cellular por seis mezes a dous annos

Vê-se, assim, que, inicialmente, o Código Penal dividiu as mulheres entre honestas e prostitutas, e determinou que essas duas categorias de mulheres não receberiam a mesma proteção estatal.

Posteriormente, a definição de honestidade, para o Direito Penal, ganhou novas dimensões. A mulher desonesta não precisaria, necessariamente, ser prostituta, bastava que ela não seguisse "os padrões de moralidade sexual impostos pelo patriarcado à mulher." 23

Isso fica bastante nítido no livro de Francisco José Viveiros de Castro, "Delitos contra a honra da mulher: adultério, defloramento, estupro", publicado em 1897, onde, logo na introdução, apresenta as "espécies de mulheres" percebidas em sua prática:

A longa experiência que tenho tido de processos desta ordem, como promotor público e juiz criminal ensinou-me que duas espécies de mulheres apresentam-se perante a justiça como víctimas de atentados contra sua honra. Umas são em verdade dignas da proteção das leis e da severidade inflexível do juiz. Tímidas, ingênuas, incautas, foram realmente victimas da força brutal do estuprador, ou dos artifícios fraudulentos do seductor. Mas há outras corrompidas e ambiciosas que procuram fazer chantage, especular com a fortuna ou a posição do homem, attribuindo-lhe a responsabilidade de uma seducção que não existiu, por que ellas propositalmente a provocaram, ou uma suposta violência, imaginária, fictícia. Conhecer os elementos característicos do

\footnotetext{
${ }^{23}$ ANDRADE, Vera Regina Pereira de. A Soberania Patriarcal: O Sistema de Justiça Criminal no
} Tratamento da Violência Sexual Contra a Mulher.In: Doutrina Brasiliera, 2009, p.68 
delicto; apreciar com perspicácia o valor das provas, para bem distinguir essas duas classes de mulheres, umas que soffrem, outras que especulam, é dever imprescindível do magistrado. Julgo, pois, útil reunir neste livro apontamentos e notas resultado de longos estudos, que talvez aproveitem aos jovens magistrados ao iniciar da carreira. ${ }^{24}$

Com o Código Penal de 1940 - que continua em vigor até hoje, com algumas alterações - o crime de estupro passou a ter como sujeito passivo qualquer mulher, não fazendo distinção entre a honesta e a prostituta. A mudança desagradou parte da doutrina, que associava a honra e a reputação da mulher unicamente à sua sexualidade, como se observa na crítica feita por Magalhães Noronha:

[s]omos do parecer que podia o legislador ter considerado à parte o estupro da prostituta[...]. O coito contra a sua vontade é um atentado à liberdade sexual e, portanto, não poderia deixar de fazer parte do Capitulo I do Título VI. Mas daí não distinguir a mulher pública da honesta parece-nos haver grande distância [...] A meretriz estuprada, além da violência que sofreu, não suporta outro dano. Sem reputação e honra, nada tem a temer como consequência do crime. ${ }^{25}$

Apesar de ter sido retirada do crime de estupro, a expressão "mulher honesta" continuou presente, até 2005, em outros dois crimes contra a liberdade sexual: a posse sexual mediante fraude (art. 215) e o atentado ao pudor mediante fraude (art. 216):

\section{Posse sexual mediante fraude}

Art. 215 - Ter conjunção carnal com mulher honesta, mediante fraude

$$
\text { (...) }
$$

\section{Atentado ao pudor mediante}

Art. 216 - Induzir mulher honesta, mediante fraude, a praticar ou permitir que com ela se pratique ato libidinoso diverso da conjunção carnal

A grande preocupação da doutrina era definir, precisamente, quem eram as mulheres honestas para poder diferenciá-las das desonestas. A definição apresentada por Nelson Hungria foi uma das mais adotadas:

A vítima deve ser mulher honesta, e como tal se entende, não somente aquela cuja conduta, sob o ponto de vista da moral sexual, é irrepreensível, senão também aquela

\footnotetext{
${ }^{24}$ CASTRO, Francisco José Viveiros de. Os delictos contra a honra da mulher: adultério, defloramento, estupro. A sedução no direito civil. Rio de Janeiro, 1897. p. XIX

${ }^{25}$ NORONHA, E. Magalhães, Direito Penal, v. III, 22ª ed., São Paulo: Saraiva, 1995, p.105
} 
que ainda não rompeu com o minimum de decência exigido pelos bons costumes. Só deixa de ser mulher honesta (sobre o prisma jurídico penal) a mulher francamente desregrada, aquela que, inescrupulosamente, multorum libidini patet, ainda que não tenha descido à condição autêntica de prostituta. Desonesta é a mulher fácil, que se entrega a uns e outros, por interêsse ou mera depravação. ${ }^{26}$

Na mesma linha, Damázio de Jesus, que definiu a mulher honesta da seguinte forma:

[...] se conduz pelos padrões aceitos pela sociedade onde vive. É a que mantém a conduta regrada, honrada e decente, de acordo com os bons costumes. Não se exige, todavia, um comportamento irrepreensível, mormente dentro dos padrões de liberdade sexual hoje predominantes. Pautando-se a mulher pelo mínimo de decência exigido pelos nossos costumes, será honesta. ${ }^{27}$

Já a mulher desonesta, para o autor, além das prostitutas, é aquela:

[...] mulher fácil, que se entrega a todos que a desejam, que desrespeita franca e abertamente as convenções sociais, somente se diferenciando das prostitutas por não exigir pagamento por seus favores. É a mulher de vários homens, desregrada e de costumes dissolutos, que se entrega por interesse ou depravação, sem guardar $o$ mínimo de ética sexual exigível. ${ }^{28}$

Com a promulgação da Constituição de 1988, que determinou o tratamento isonômico entre homens e mulheres, alguns autores começaram a sustentar a inconstitucionalidade dessa categorização das mulheres, uma vez que não existia a expressão "homem honesto", e essa disposição finalmente começou a ser questionada por parte da doutrina.

Merece destaque as reflexões feitas por Guilherme Nucci sobre o tema:

Seria honesta, atualmente, a mulher que tomasse a iniciativa da conquista e investisse sobre os parceiros, exatamente como faz o homem com relação à mulher? Seria honesta a mulher que apreciasse o sexo, exatamente como sempre se incentivou o homem a fazer, trocando de parceiros várias vezes? Se a resposta for afirmativa, fruto natural da libertação sexual, não há, de fato, razão para a existência do tipo penal do art. 215, que somente poderia ter em vista proteger exceções. De outra parte, se a

\footnotetext{
${ }^{26}$ HUNGRIA, Nelson; LACERDA, Romão Cortes de. Comentários ao Código Penal, t. VIII, Rio de Janeiro: Forense, 1947 p.139.

${ }^{27}$ JESUS, Damásio. Direito Penal:parte especial, v. III, 14ª ed., São Paulo: Saraiva, 1999, p.109.

${ }^{28}$ Ibdem, p. 109-110.
} 
resposta for negativa está-se diante de um impasse, pois a interpretação valorativa do termo inserido no tipo penal demonstraria seu descompasso com a realidade. ${ }^{29}$

Embora posições contrárias à concepção de mulher honesta começassem a aparecer na doutrina pátria de forma isolada, a jurisprudência dos Tribunais Superiores ainda discutia sobre o conceito de honestidade. Em agosto de 2002, o Superior Tribunal de Justiça pacificou seu entendimento:

A expressão "mulher honesta", como sujeito passivo do crime de posse sexual mediante fraude, deve ser entendida como a mulher que possui certa dignidade e decência, conservando os valores elementares do pudor, não sendo necessário, portanto, a abstinência ou o desconhecimento a respeito de prática sexual. ${ }^{30}$

Foi somente em 2005, com a publicação da Lei 11.106/05, que a expressão foi definitivamente retirada da legislação penal pátria. Apesar disso, a lógica da honestidade, que já se encontra profundamente sedimentada, permanece viva até hoje nos julgamentos dos crimes sexuais, que mais parecem julgamentos da reputação da mulher para decidir se ela pode ou não ocupar o papel de vítima.

Como explica Vera Andrade, no campo dos crimes sexuais, o sistema penal promove uma verdadeira inversão dos papéis e do ônus da prova ${ }^{31}$ :

A vítima que acessa o sistema requerendo o julgamento de uma conduta definida como crime - a ação, regra geral é de iniciativa privada - acaba por ver-se ela própria "julgada" (pela visão masculina da lei, da polícia e da Justiça), incumbindo-lhe provar que é uma vítima real e não simulada.

A autora continua:

Tem sido reiteradamente posto em relevo a maneira como as demandas femininas são submetidas a um intensa "hermenêutica da suspeita", do constrangimento e da humilhação ao longo do inquérito policial e do processo penal que vasculha a moralidade da vítima (para ver se é ou não uma vítima apropriada), sua resistência (para ver se é ou não uma vítima inocente), reticente a condenar somente pelo exclusivo testemunho da mulher (dúvidas acerca da sua credibilidade).

${ }^{29}$ NUCCI, Guilherme de Souza. Código Penal comentado. 4. ed., São Paulo: Revista dos TRibunais, 2003, p. 674.

${ }^{30}$ Código penal e sua interpretação jurisprudencial, v.I, 7. ed. São Paulo: Revista dos Tribunais, 2001.

31 ANDRADE, Vera Regina Pereira de. A Soberania Patriarcal: O Sistema de Justiça Criminal no Tratamento da Violência Sexual Contra a Mulher.In: Doutrina Brasiliera, 2009, p. 70. 
Em suma, as mulheres que permanecem estereotipadas como "desonestas" do ponto de vista da moral sexual, não apenas não são consideradas vítimas pelo sistema, como também podem ser convertidas de vítimas em acusadas, em um nível crescente de argumentação que inclui elas terem "consentido", "gostado", "tido prazer", "provocado" ou até mesmo "forjado o estupro".

Por outro lado, é interessante notar que a honestidade masculina jamais teve qualquer relação com sua sexualidade. Muito pelo contrário, esta torna o homem viril, engrandece-o. $\mathrm{O}$ homem sempre pode ter várias mulheres ao longo de sua vida e isso nunca foi uma questão para a legislação penal brasileira. Prova disso é o antigo crime de adultério, hoje já revogado.

Assim dispunha o Código Penal de 1830:

\section{Adulterio}

Art. 250. A mulher casada, que commetter adulterio, será punida com a pena de prisão com trabalho por um a tres annos.

A mesma pena se imporá neste caso ao adultero.

Art. 251. O homem casado, que tiver concubina, teúda, e manteúda, será punido com as penas do artigo antecedente.

Observa-se que apesar das penas previstas para o homem e para a mulher serem iguais, apenas a mulher era denominada adúltera. O homem só seria punido se praticasse uma conduta específica e de difícil definição, qual seja, ter uma "concubina, teúda e manteúda".

$\mathrm{Na}$ verdade, o adultério masculino era socialmente aceito. O que o Estado queria impedir era tão somente que ele mantivesse uma relação extraconjugal estável com outra mulher, de modo que passasse a sustentá-la, gerando, assim, prejuízos econômicos para sua família. $\mathrm{O}$ adultério feminino, por sua vez, era visto como muito mais gravoso, pois poderia trazer uma prole ilegítima para o seio do casamento, abalando a reputação do marido. 
Sobre essa visão, explica Lopes de Oliveira (1991):

Quando um homem viola a lealdade conjugal, ele o faz por causa de um desejo fútil. Isto não destrói o amor da mulher, ou o fundamento da sociedade conjugal. $\mathrm{O}$ adultério da mulher, ao contrário, afeta a ordem interna da família, comprometendo a estabilidade da vida conjugal. $\mathrm{O}$ adultério da mulher é mais sério, não somente pelo escândalo que causa, mas também porque fere um maior número de valores e a lei mais profundamente. Há perigo de a mulher introduzir crianças estranhas dentro do $\operatorname{lar}^{32}$

A citação acima confirma duas noções sobre o adultério: i) se praticado por mulheres era socialmente inaceitável, pois ia contra seus papéis de mães e progenitoras da nação; e ii) por outro lado, os homens estavam livres para preencherem seus desejos pessoais quase sem qualquer reprimenda social. ${ }^{33}$

No Código Penal de 1940 não havia mais diferenciação entre a prática dessa conduta pelo homem ou pela mulher. Surgiu, porém, a tese da "legítima defesa da honra", usada para tornar impune as agressões e homicídios de mulheres por parte de seus (ex) companheiros quando estas praticavam o adultério. Inaugurou-se, assim, a modalidade de crimes passionais.

Isso se perpetuou até o final da década de 1970 e início da década de 1980, quando o movimento feminista direcionou seu foco para erradicação desse problema. $\mathrm{O}$ estopim para que as mulheres se organizassem de forma pública e organizada contra a impunidade masculina ocorreu em outubro de 1979, na ocasião do julgamento de Doca Street pelo assassinato de sua companheira Angela Diniz, ocorrido em dezembro de 1976.

Street, inconformado com o término do relacionamento matou Diniz com quatro tiros à queima roupa. Em seu primeiro julgamento, a defesa embasou-se na tese da legitima defesa da honra, buscando demonstrar que a vítima era uma mulher bonita, fútil, egoísta, de vida fácil e desregrada, que seduzia e abandonava os homens, sendo o réu mais uma de suas vítimas de sedução. A imprensa contribuiu para difundir esses argumentos e Street recebeu uma pena mínima de dois anos com

32 OLIVEIRA, Lopes de. Criminal injustice: Violence against women in Brazil. Human Rights Watch: New York. 1991. p. 22 
surcis. Na verdade, era como se o assassino tivesse livrado a sociedade de uma mulher que punha em risco a moral da "família tradicional brasileira". ${ }^{34}$

O caso foi amplamente divulgado pela mídia e as mulheres se articularam e exerceram forte pressão no segundo julgamento, utilizando o slogan "Quem ama não mata", que se tornou o símbolo da rejeição ao termo "crime passional". Doca Street foi, então, condenado a 15 anos de prisão.

Após esse evento, o movimento feminista ganhou força e insuflou o combate por um sistema de justiça livre de discriminações de gênero. As mulheres começaram a se organizar politicamente e a traçar formas de enfrentar as violências perpetradas, observando a necessidade de políticas públicas específicas e direcionadas que pudessem transformar a relação entre homens e mulheres marcada pela subordinação e desigualdade, tanto na esfera pública quanto privada. A partir daí as coisas começaram a mudar.

${ }^{33}$ SOUZA Eros de; BALDWIN, John R, ROSA Francisco Heitor da. A Construção Social dos Papéis Sexuais Femininos. In: Psicologia: Reflexão e Crítica, 2000, p. 489.

34 Artigo publicado pelo Instituto Patrícia Galvão, 2016. Disponível em: http://agenciapatriciagalvao.org.br/violencia/memoria-40-anos-do-feminicidio-de-angela-diniz/> 


\section{O TRATAMENTO DADO À VIOLÊNCIA DOMÉSTICA NO BRASIL}

\subsection{O CONTEXTO HISTÓRICO NACIONAL}

O ano de 1985 foi marcante na história da luta do movimento feminista contra a violência de gênero no Brasil. Como reflexo da mobilização iniciada no final da década de 1970 contra a impunidade masculina, foram criados, naquele ano, durante o governo de José Sarney, o Conselho Nacional dos Direitos das Mulheres (CNDM), junto ao Ministério da Justiça, bem como a primeira Delegacia de Defesa da Mulher (DDM), em São Paulo.

O CNDM tinha como finalidade promover políticas que visassem a eliminar a discriminação da mulher, assegurando-lhe condições de liberdade e de igualdade de direitos, além de sua plena participação nas atividades políticas, econômicas e culturais do país. $^{35}$ Articulado com diversos núcleos do movimento feminista nacional, empenhou-se para conscientizar a sociedade civil e a Assembleia Constituinte acerca dos direitos da mulher, que precisavam restar assegurados pela nova Constituição. Essa articulação política ficou conhecida como Lobby do Batom.

Como relata Cíntia Regina Béo,

durante os trabalhos da Assembléia Constituinte de 1988, foi muito atuante junto aos constituintes e à opinião pública, o chamado 'lobby do batom', que tinha como objetivo fazer com que houvesse um reconhecimento constitucional da igualdade entre homens e mulheres e de instrumentos capazes de assegurar esta igualdade

${ }^{35}$ Art. $1^{\circ}$ da Lei $n^{\circ} 7.353 / 85$. 
futuramente, já que a mera declaração constitucional não teria o condão de alterar a realidade e as barreiras sociais impostas à mulher. ${ }^{36}$

No plano internacional, o Brasil também era pressionado para garantir a igualdade entre homens e mulheres. Isso porque, em 1984, o país ratificou a Convenção sobre a Eliminação de todas as formas de Discriminação contra a Mulher (CEDAW), onde os Estados-partes comprometiam-se a adotar as seguintes medidas $^{37}$ :

a) consagrar, se ainda não o tiverem feito, em suas Constituições nacionais ou em outra legislação apropriada, o princípio da igualdade do homem e da mulher e assegurar por lei outros meios apropriados à realização prática desse princípio;

b) adotar as medidas adequadas, legislativas e de outro caráter, com as sanções cabíveis e que proíbam toda discriminação contra a mulher;

c) estabelecer a proteção jurídica dos direitos da mulher em uma base de igualdade com os do homem e garantir, por meio dos tribunais nacionais competentes e de outras instituições públicas, a proteção efetiva da mulher contra todo ato de discriminação;

d) abster-se de incorrer em todo ato ou prática de discriminação contra a mulher e zelar para que as autoridades e instituições públicas atuem em conformidade com esta obrigação;

e) tomar as medidas apropriadas para eliminar a discriminação contra a mulher praticada por qualquer pessoa, organização ou empresa;

f) adotar as medidas adequadas, inclusive de caráter legislativo, para modificar ou derrogar leis, regulamentos, usos e práticas que constituam discriminação contra a mulher;

g) derrogar todas as disposições penais nacionais que constituam discriminação contra a mulher.

Como resultado da pressão interna e externa, foram aprovadas $80 \%$ das pautas feministas no texto da Constituição ${ }^{38}$, que passou a assegurar não somente a

36 BÉO, Cíntia Regina. A sistematização e a hermenêutica como instrumentos garantidores da efetividade dos direitos da mulher na Constituição Federal de 1988. Tese de doutorado apresentada à Faculdade de Direito da Universidade de São Paulo, 2006, p. 85.

37 Art. $2^{\circ}$ da CEDAW.

${ }^{38}$ ANDRADE, Luciana Vieira Rubim; ALMEIDA, Marlise Miriam de Matos. Criminalização Da Violência Contra As Mulheres No Brasil: De "Legítima Defesa Da Honra" À Violação Dos Direitos Humanos. In: Revista Socais \& Humanas CCSH/UFSM. 2017. p. 7. 
igualdade entre homens e mulheres (art. $5^{\circ}$, I), como também a punição de qualquer ato discriminatório que atentasse aos direitos e liberdades fundamentais (art. $5^{\circ}, \mathrm{XLI}$ ). No tocante à violência doméstica, foi inserido no art. 226, §8 $8^{\circ}$ que "O Estado assegurará a assistência à família na pessoa de cada um dos que a integram, criando mecanismos para coibir a violência no âmbito de suas relações."

Paralelamente ao processo de redemocratização, expandiam-se, pelo território brasileiro, as Delegacias de Defesa da Mulher (DDMs). A motivação para o fomento dessas instituições deveu-se à necessidade de se criar espaços em que as mulheres pudessem se sentir seguras para relatar os episódios de violência que vivenciavam e para os quais poderiam buscar uma resposta jurídico-penal.

Antes da criação das DDMs eram as próprias feministas que acabavam exercendo esse trabalho, uma vez que o Estado não demonstrava nenhuma intenção de fazê-lo. Através da ONG SOS Mulher, atuavam diretamente com a questão da violência contra as mulheres no Brasil, prestando serviços de assistência social e orientação jurídica e psicológica às mesmas.

Apesar de efêmera, a experiência com o SOS Mulher foi de suma importância, pois começou a dar visibilidade ao fenômeno da violência doméstica que, até então, era tratado como um problema intrafamiliar. Por meio dessa ONG, iniciou-se um diálogo com o governo, uma vez que as feministas perceberam que era impossível que organizações não governamentais tomassem para si todas as responsabilidades que teriam que ser ocupadas majoritariamente pelo Estado.

O movimento feminista buscava demonstrar que a violência contra a mulher é um problema social, que demanda medidas específicas em seu combate. Dentre elas, seria preciso estabelecer um sistema que pudesse receber de forma mais acolhedora as mulheres que decidissem denunciar seus agressores, garantindo-lhes a segurança de que seriam efetivamente tomadas as medidas para investigação e punição do crime. 
A pesquisa de Danielle Ardaillon e Guita Grin Debert ${ }^{39}$ sobre os processos relacionados à violência doméstica, publicada em 1987, demonstra a importância da criação de delegacias especializadas no atendimento das mulheres. As autoras constataram que, no tocante à violência física, havia a tendência, por parte das instâncias de justiça, de avaliar a atuação do agressor no seio doméstico. Assim, muito se repetia, nas delegacias e nos tribunais, sobre o papel do homem como "bom pai" ou "provedor", como forma de amenizar sua conduta violenta.

Relataram, ainda, a frequência com que era questionada, institucionalmente, a iniciativa feminina em realizar a denúncia, principalmente se o foco desta não fosse a primeira agressão. $\mathrm{O}$ fato de a mulher ter sofrido violência física anteriormente sem ter noticiado à polícia parecia deslegitimar sua demanda, soando o processo judicial como uma espécie de barganha na relação marido e mulher. De maneira paradoxal, a reincidência acabaria por relativizar o crime, já que, pela ótica policial, não seria coerente que a mulher denunciasse uma prática sobre a qual já houvesse se silenciado em um momento anterior. A mesma pesquisa revelou a pressão exercida por parte dos delegados para que a mulher se reconciliasse com seu agressor, sob argumentos de "manutenção da coesão familiar".

Assim, a instalação das DDMs foi uma grande conquista para a emancipação feminina. Como relata Mariana Guimarães Rocha da Cunha Bueno, "O serviço era prestado apenas por funcionárias mulheres, devidamente capacitadas para o atendimento, que deveriam tratar as vítimas sem os preconceitos, humilhações e desinteresse normalmente verificados nas delegacias comuns. ${ }^{140}$

Muito mais do que um local de coleta de ocorrências, as DDMs acabaram identificando-se como a maior via de visibilidade da violência contra a mulher, de onde era possível colher dados sobre os tipos de violência praticadas, perfil de vítima e agressor, consequências jurídicas ansiadas pela mulher e outras demandas

\footnotetext{
${ }^{39}$ ARDAILLON, Danielle; DEBERT, Guita Grin. Quando a vítima é mulher: análise de julgamentos de crimes de estupro, espancamento e homicídio. Brasília: Conselho Nacional dos Direitos da Mulher, 1987.

${ }^{40}$ BUENO, Mariana Guimarães Rocha da Cunha. Feminismo e Direito Penal. Dissertação de Mestrado apresentada na USP. São Paulo: 2011, p. 131.
} 
específicas do fenômeno da violência de gênero. Os números de ocorrência de violência perpetrada por pais, companheiros e irmãos ganharam destaque. As mulheres incentivavam-se a denunciar, já que não mais se sentiam isoladas e, assim, a violência doméstica deixava de ser uma questão privada, para invadir o espaço público. ${ }^{41}$

A não suficiência da oferta de uma resposta penal tornou-se evidente na prática cotidiana das DDMs, tanto pelo fato de a punição não ser capaz de transformar o comportamento dos agressores, quanto por, muitas vezes, não ser esta a resposta desejada pela vítima. Nesse sentido, houve uma tendência por parte das mulheres em situação de violência em considerar a DDM como instância não só de penalização dos agressores, mas também - e principalmente - de acolhimento, assemelhando-se a um núcleo de assistência social para onde as mulheres se encaminhavam para desabafar sobre queixas e também para intimidar os companheiros e maridos violentos. ${ }^{42}$

As DDMs tornaram-se, assim, um recurso simbólico para que as mulheres negociassem suas relações familiares, o que fez com que a instituição sofresse uma ressignificação: de um canal para lutar contra a impunidade, tornou-se uma via de busca pela libertação das violências de gênero e pela própria autonomia, ainda que, institucionalmente, não fosse possível responder a essa expectativa. ${ }^{43}$

Tudo parecia caminhar relativamente bem até a promulgação da Lei 9.099/95, responsável por criar os Juizados Especiais Criminais para julgar os crimes de menor potencial ofensivo, isto é, aqueles cuja pena máxima não ultrapassa 2 (dois) anos. Por serem considerados crimes de menor relevância, em razão de sua baixa lesividade, a lei estipula uma simplificação dos procedimentos, marcados pela oralidade,

\footnotetext{
${ }^{41}$ COUTO, Maria Cláudia Girotto. Lei Maria da Penha e Princípio da Subsidiariedade. São Paulo. 2016. Dissertação de mestrado defendida na USP, p. 49.

${ }^{42}$ GREGORI, Maria Filomena. Delegacias de Defesa da Mulher de São Paulo e as instituições: paradoxos e paralelismos. In DEBERT, Guita G.; GREGORI, Maria Filomena; e PISCITELLI, Adriana (orgs.). Gênero e Distribuição da Justiça: as delegacias de defesa da mulher na construção das diferenças. Coleção Encontros. Campinas: Pagu/Unicamp, 2006, p. 5
} 
informalidade, e economia processual. Ademais, prevê uma série de medidas despenalizadoras, como a transação penal, a suspensão condicional do processo e a conciliação entre as partes, com o intuito de se evitar a instauração do processo penal, que por si só já é estigmatizante.

Não se tem a intenção aqui de deslegitimar a instalação desses juizados, muito pelo contrário, eles foram um grande avanço para um sistema de justiça criminal um pouco mais garantista. $\mathrm{O}$ grande problema foi que a maioria dos crimes cometidos contra as mulheres em seio doméstico (lesão corporal de natureza leve, ameaça e crimes contra a honra) acabaram por se enquadrar no conceito de crime de menor potencial ofensivo trazido pela nova lei, que não levava em consideração as particularidades dessa modalidade de violência.

Possuindo a agressão ocorrida contra a mulher, no âmbito doméstico e familiar, uma carga simbólica muito distinta daquela que ocorre entre duas pessoas estranhas, por todas as razões já apontadas no primeiro capítulo, mostrava-se inadequado que o diploma legal a tratasse como uma conduta de baixa lesividade. Instaurou-se uma sensação de impunidade e de não relevância social da violência doméstica e o movimento feminista, viu-se, assim, diante de uma nova batalha.

\section{Como analisa Maria Cláudia Girotto Couto,}

O movimento feminista teceu críticas contundentes ao modo com que o novo diploma legal estava sendo aplicado aos casos de violência doméstica. A forma com que os crimes-objeto dos Juizados foi definida, a saber, "crimes de menor potencial ofensivo", e sua aplicação a agressões domésticas, foi apontada como responsável por banalizar tais condutas e atribuir-lhes a pecha de crimes irrelevantes, como se não representassem lesividade bastante para o Direito e para a sociedade. ${ }^{44}$

Em que pese as diversas críticas à lógica punitivista que serão tecidas mais adiante, a demanda por um agravamento das punições pela prática de violências ocorridas em âmbito doméstico se apresentou, naquele momento, como um

\footnotetext{
${ }^{43}$ DEBERT, Guita Grin. Conflitos éticos nas Delegacias de Defesa da Mulher cit., p. 26, GREGORI, Maria Filomena. Delegacias de Defesa da Mulher de São Paulo e as instituições cit., p. 70 e IZUMINO, Wania Pasinato. Delegacias de Defesa da Mulher e Juizados Especiais Criminais cit., p. 5. ${ }^{44}$ COUTO, Maria Cláudia Girotto. Lei Maria da Penha e Princípio da Subsidiariedade. São Paulo. 2016. Dissertação de mestrado defendida na USP, p 51.
} 
reconhecimento da valorização diferenciada do significado dessa violência, por toda a sua carga histórica e simbólica.

Uma outra questão que se apresentou com a entrada em vigor da Lei 9.099/95 foi o esvaziamento das DDMs, uma vez que crimes de menor potencial ofensivo não necessitam de inquérito policial. $\mathrm{O}$ atendimento às mulheres passou a ser feito nos próprios JECRIMs, cujos funcionários não dispunham de capacitação para lidar com vítimas de violência doméstica. Assim, as mulheres voltaram a enfrentar o mesmo tipo de problema da época em que tinham que recorrer às delegacias comuns.

Carmem Hein de Campos observa que há dificuldade por parte dos operadores do Direito na compreensão do esforço envolvido na realização de uma queixa e em se ponderar a existência de inseguranças e incertezas diversas. Segundo a autora,

Eles ignoram, por exemplo, que as inúmeras denúncias nas delegacias são tentativas de confiar no sistema legal e fazem parte do processo de ruptura do denominado ciclo da violência doméstica. A mulher agredida não é uma mulher irracional, que não sabe o que quer. É uma mulher que está buscando, por meio de vários mecanismos, mudar a situação de violência. Como consequência, o tratamento jurídico dispensado a estes casos será fundamental para a mudança da situação e para a confiabilidade futura no sistema. ${ }^{45}$

$\mathrm{Na}$ tentativa de amenizar as críticas foram promulgadas duas leis prevendo dispositivos específicos para a violência doméstica:

(i) A Lei 10.455/02 alterou o art. 69 da Lei 9.099/95 para acrescentar uma medida cautelar que poderia ser aplicada pelo juízo consistente no afastamento do agressor do lar, domicílio ou local de convivência com a vítima; e

(ii) A Lei 10.886/04 acrescentou ao art. 129 o tipo especial de violência doméstica nos crimes de lesão corporal de natureza leve, aumentando a pena em 1/3 (um terço). ${ }^{46}$

45 CAMPOS, Carmen Hein de. Violência Doméstica e Direito Penal Crítico. In: JONAS, Eline. Violências esculpidas. Goiânia: Editora da UCG, 2007. p. 146.

46 Art. $129 \$ 9^{\circ}$. Se a lesão for praticada contra ascendente, descendente, irmão, cônjuge ou companheiro, ou com quem conviva ou tenha convivido, ou, ainda, prevalecendo-se o agente das relações domésticas, de coabitação ou de hospitalidade. $\S 10^{\circ}$. Nos casos previstos nos $\S \S 1^{\circ}$ a $3^{\circ}$ deste artigo, se as circunstâncias são as indicadas no $\S 9^{\circ}$ deste artigo, aumenta-se a pena em 1/3 (um terço). 
Essas alterações legislativas, porém, não foram consideradas suficientes pelo movimento feminista, na medida em que as agressões usuais da violência doméstica continuavam configurando crimes de menor potencial ofensivo. Intensificou-se, assim, a pressão para a criação de uma legislação especial que tratasse especificamente da violência doméstica contra a mulher, com todas as suas particularidades.

No plano internacional, o Brasil também era pressionado.

\subsection{OS INSTRUMENTOS INTERNACIONAIS NO COMBATE À VIOLÊNCIA CONTRA A MULHER}

Foi em 1993, que a Assembleia Geral das Nações Unidas adotou a Declaração sobre a Eliminação da Violência contra a Mulher, definindo, em seu artigo $1^{\text {o }}$, que constitui violência contra a mulher

qualquer ato de violência baseado no gênero que resulte, ou possa resultar, em dano físico, sexual ou psicológico ou em sofrimento para a mulher, inclusive ameaças de tais atos, coerção ou privação arbitrária da liberdade, podendo ocorrer na esfera pública ou na esfera privada.

Como menciona Flávia Piovesan, a Declaração trouxe uma grande inovação quando reconheceu, expressamente, que a violência contra a mulher não está limitada ao âmbito público das relações, ocorrendo, também, em seu domínio privado. ${ }^{47}$

Além disso, ela representou um compromisso por parte dos Estados em tomarem todas as medidas apropriadas para abolir leis, costumes, regras e práticas existentes que constituíssem discriminação contra a mulher, bem como para educar a opinião pública e dirigir as aspirações nacionais para a erradicação do preconceito e

\footnotetext{
47 PIOVESAN, Flávia. Direitos humanos e o direito constitucional internacional. $11^{\text {a }}$ ed. São Paulo: Editora Saraiva, 2010. p. 206.
} 
abolição dos costumes e de todas as outras práticas que estivessem baseadas na ideia de inferioridade feminina. ${ }^{48}$

No ano seguinte, em 1994, realizou-se a Convenção Interamericana para Prevenir, Punir e Erradicar a Violência contra a Mulher (Convenção de Belém do Pará).

Seguindo a Declaração sobre a Eliminação da Violência contra a Mulher, a Convenção de Belém do Pará ampliou o âmbito de proteção da mulher, invadindo o espaço das relações privadas para alcançar toda sorte de violência baseada no gênero.

Nesse sentido, o art. $2^{\circ}$ da Convenção estabelece que:

Entende-se que a violência contra a mulher abrange a violência física, sexual e psicológica:

a. ocorrida no âmbito da família ou unidade doméstica ou em qualquer relação interpessoal, quer o agressor compartilhe, tenha compartilhado ou não a sua residência, incluindo-se, entre outras formas, o estupro, maustratos e abuso sexual;

b. ocorrida na comunidade e cometida por qualquer pessoa, incluindo, entre outras formas, o estupro, abuso sexual, tortura, tráfico de mulheres, prostituição forçada, sequestro e assédio sexual no local de trabalho, bem como em instituições educacionais, serviços de saúde ou qualquer outro local; e

c. perpetrada ou tolerada pelo Estado ou seus agentes, onde quer que ocorra.

Em 1998, a Comissão Interamericana de Direitos Humanos recebeu uma denúncia, apresentada por Maria da Penha Maia Fernandes, em conjunto com o Centro pela Justiça e pelo Direito Internacional (CEJIL) e pelo Comitê LatinoAmericano de Defesa dos Direitos da Mulher (CLADEM), reportando os episódios de violência doméstica dos quais Maria da Penha fora vítima, dentre os quais se destacam duas tentativas de homicídio por parte de seu ex marido: a primeira foi um tiro que a deixou paraplégica; já a segunda, uma descarga elétrica durante o banho.

\footnotetext{
$48 \quad$ Arts. $\quad 2^{\circ} \quad$ e $\quad 3^{\circ}$ da $\quad$ Declaração. Disponível em: <http://www.apf.pt/sites/default/files/media/2015/1967_declaracao_sobre_a_eliminacao_da_discrimin acao_contra_as_mulheres.pdf> acessado em 15 maio 2018
} 
Acusava-se o Estado Brasileiro de tolerância para com a violência cometida, na medida em que, decorridos mais de 15 anos da data dos fatos, não se tinha tomado as medidas necessárias para processar e punir o agressor, apesar das denúncias efetuadas.

\section{A Comissão Interamericana de Direitos Humanos chegou à seguinte} conclusão sobre o caso:

1. Que tem competência para conhecer deste caso e que a petição é admissível em conformidade com os artigos 46.2,c e 47 da Convenção Americana e com o artigo 12 da Convenção de Belém do Pará, com respeito a violações dos direitos e deveres estabelecidos nos artigos 1(1) (Obrigação de respeitar os direitos), 8 (Garantias judiciais), 24 (Igualdade perante a lei) e 25 (Proteção judicial) da Convenção Americana em relação aos artigos II e XVIII da Declaração Americana, bem como no artigo 7 da Convenção de Belém do Pará.

2. Que, com fundamento nos fatos não controvertidos e na análise acima exposta, a República Federativa do Brasil é responsável da violação dos direitos às garantias judiciais e à proteção judicial, assegurados pelos artigos 8 e 25 da Convenção Americana em concordância com a obrigação geral de respeitar e garantir os direitos, prevista no artigo 1(1) do referido instrumento pela dilação injustificada e tramitação negligente deste caso de violência doméstica no Brasil.

3. Que o Estado tomou algumas medidas destinadas a reduzir o alcance da violência doméstica e a tolerância estatal da mesma, embora essas medidas ainda não tenham conseguido reduzir consideravelmente o padrão de tolerância estatal, particularmente em virtude da falta de efetividade da ação policial e judicial no Brasil, com respeito à violência contra a mulher.

4. Que o Estado violou os direitos e o cumprimento de seus deveres segundo o artigo 7 da Convenção de Belém do Pará em prejuízo da Senhora Fernandes, bem como em conexão com os artigos 8 e 25 da Convenção Americana e sua relação com o artigo 1(1) da Convenção, por seus próprios atos omissivos e tolerantes da violação infligida. ${ }^{49}$

Assim, em 2006, como forma de se adequar às exigências advindas do contexto internacional, bem como em razão da pressão exercida pelo movimento feminista, foi publicada a Lei 11.340/06, que recebeu o nome de Lei Maria da Penha.

${ }^{49}$ Relatório do caso 12.051, de 04 de abril de 2001, emitido pela Comissão Interamericana de Direitos 


\subsection{A LEI MARIA DA PENHA}

A Lei Maria da Penha (Lei 11.340/06) entrou no ordenamento pátrio a fim de preencher as lacunas normativas advindas das disposições presentes na Constituição Brasileira de 1988, na Convenção da ONU sobre a Eliminação de Todas as Formas de Discriminação Contra as Mulheres e na Convenção Interamericana para Prevenir, Punir e Erradicar a Violência Contra a Mulher.

Destaca-se que, em sua redação, optou-se pelo uso da expressão "mulheres em situação de violência" em detrimento de "mulheres vítimas de violência". Essa escolha teve como intuito refutar que à mulher caberia uma posição passiva diante do agressor e destacar que a situação de vítima é (ou pode ser) transitória. Visou-se romper com termos que pudessem estigmatizar a mulher a fim de deslocá-la para o lugar de sujeito. ${ }^{50}$

Em seu art. $5^{\circ}$ estabelece que configura violência doméstica e familiar contra a mulher qualquer ação ou omissão baseada no gênero que lhe cause morte, lesão, sofrimento físico, sexual ou psicológico e dano material ou patrimonial desde que ocorra em três contextos, a saber:

I - no âmbito da unidade doméstica, compreendida como o espaço de convívio permanente de pessoas, com ou sem vínculo familiar, inclusive as esporadicamente agregadas;

II - no âmbito da família, compreendida como a comunidade formada por indivíduos que são ou se consideram aparentados, unidos por laços naturais, por afinidade ou por vontade expressa;

III - em qualquer relação íntima de afeto, na qual o agressor conviva ou tenha convivido com a ofendida, independentemente de coabitação.

Como analisa Carmem Hein de Campos, a Lei 11.349/06 tratou a violência doméstica de forma integral, aliando medidas de assistência, prevenção e contenção

Humanos. Disponível em <http://www.cidh.oas.org/annualrep/2000port/12051.htm>. Acessado em 15 maio 2018. 
da violência, sem se restringir à uma lógica punitiva. Dentre as medidas destacam-se: 51

(a) os programas de longo prazo como planejamento das políticas públicas, promoção de pesquisas e estatísticas, controle da publicidade sexista, inclusão de conteúdos relativos aos direitos humanos e à equidade de gênero nos currículos escolares de todos os níveis de ensino;

(b) as medidas emergenciais como a criação de cadastro de programas assistenciais governamentais nos quais as mulheres em situação de violência doméstica tenham prioridade de assistência, sobretudo quando há risco à sua integridade física e psicológica, a previsão de remoção ou de afastamento do trabalho de forma prioritária quando a servidora pública é vítima ou sua integridade física e psíquica encontra-se em risco, e a separação de corpos, com a retirada do agressor do lar; e

(c) as medidas de proteção ou contenção da violência como a criação de centros de educação e reabilitação para os agressores, programas de atendimento ou proteção para as vítimas, fornecimento de assistência judiciária gratuita, e a possibilidade de atendimento por equipe multidisciplinar integrada por profissionais das áreas psicossocial, jurídica e de saúde. Dentre as atribuições dessa equipe, estão as tarefas de "desenvolver trabalhos de orientação, encaminhamento, prevenção e outras medidas, voltados para a ofendida, o agressor e os familiares, com especial atenção às crianças e aos adolescentes".

Essa especial atenção às crianças e aos adolescentes é um aspecto que merece ser ressaltado. Para além da mulher, existem as vítimas indiretas da violência doméstica, que são, principalmente, os filhos que presenciam os maus-tratos. Essas

\footnotetext{
${ }^{50}$ CAMPOS, Carmen Hein de. Disposições preliminares - art. $1 .^{\circ}, 2^{\circ}, 3 .^{\circ}$ e $4 .^{\circ}$. In: Campos, Carmen Hein de (org.). Lei Maria da Penha comentada em uma perspectiva jurídico-feminista. Rio de Janeiro: Lumen Juris, 2011. p. 178.

${ }^{51}$ CAMPOS, Carmem Hein de; CARVALHO, Salo. Tensões Atuais entre a Criminologia Feminista e a Criminologia Crítica: a Experiência Brasiliera.2014, p. 143 . disponível em: <http://www.compromissoeatitude.org.br/wp-content/uploads/2014/02/1_8_tensoes-atuais.pdf> acessado em 17 maio 218,
} 
crianças têm maior risco de reproduzirem esse padrão de comportamento, em razão da transmissão intergeracional da violência por meio da aprendizagem social. ${ }^{52}$

Tal fenômeno ocorre porque a família desempenha um papel fundamental no processo de socialização das crianças. O âmbito familiar é o espaço onde elas paulatinamente assimilam "um complexo básico e estável de valores, ideias e padrões" de conduta, organizando os seus esquemas de referência. Assim, as pesquisas vitimológicas alertam para esse aspecto tão importante do conflito vivenciado no meio familiar: a reversibilidade das categorias de vítimas, uma vez que muitos são os infratores que foram vítimas de abusos ou maus-tratos na infância e que, quando adultos, reproduzem esse comportamento, por terem apreendido a violência como algo natural. ${ }^{53}$

Vê-se, assim, que a Lei Maria da Penha trouxe instrumentos que possuem verdadeiro potencial transformador, na medida em que poderiam garantir a proteção das mulheres e atuar diretamente na raiz da violência doméstica, que é a discriminação de gênero. Não há dúvidas de que a melhor forma de combater essa violência é através da conscientização da população, principalmente pela educação das novas gerações. Os incisos III, V, VII, VIII e IX do art. $8^{\circ}$ da Lei preveem uma série de medidas nesse sentido, a saber:

Art. $8^{\circ} \mathrm{A}$ política pública que visa coibir a violência doméstica e familiar contra a mulher far-se-á por meio de um conjunto articulado de ações da União, dos Estados, do Distrito Federal e dos Municípios e de ações não-governamentais, tendo por diretrizes:

(...)

III - o respeito, nos meios de comunicação social, dos valores éticos e sociais da pessoa e da família, de forma a coibir os papéis estereotipados que legitimem ou exacerbem a violência doméstica e familiar, de acordo com o estabelecido no inciso III do art. $1^{\circ}$, no inciso IV do art. $3^{\circ}$ e no inciso IV do art. 221 da Constituição Federal;

(...)

V - a promoção e a realização de campanhas educativas de prevenção da violência doméstica e familiar contra a mulher, voltadas ao público escolar e à sociedade em

\footnotetext{
${ }^{52}$ CARO, Maria Del Castillo Falcón. Realidad Individual, social y jurídica de la mujer víctima de la violencia de género. In: MORENO, Myriam Herrera (Coord.). Hostigamento y hábitat social: una perspectiva victimológica. Granada: Editorial COMARES, 2008. p. 34.

${ }^{53}$ OLIVEIRA, Ana Sofia Schmidt de. A vítima e o direito penal: uma abordagem do movimento vitimológico e de seu impacto no direito penal. São Paulo: Revista dos Tribunais, 1999, p. 99.
} 
geral, e a difusão desta Lei e dos instrumentos de proteção aos direitos humanos das mulheres;

(...)

VII - a capacitação permanente das Polícias Civil e Militar, da Guarda Municipal, do Corpo de Bombeiros e dos profissionais pertencentes aos órgãos e às áreas enunciados no inciso I quanto às questões de gênero e de raça ou etnia;

VIII - a promoção de programas educacionais que disseminem valores éticos de irrestrito respeito à dignidade da pessoa humana com a perspectiva de gênero e de raça ou etnia;

IX - o destaque, nos currículos escolares de todos os níveis de ensino, para os conteúdos relativos aos direitos humanos, à eqüidade de gênero e de raça ou etnia e ao problema da violência doméstica e familiar contra a mulher.

Ocorre que todas essas medidas de assistência, contenção, prevenção e proteção apresentadas ainda possuem sérios problemas de implementação e de acesso, especialmente nas comunidades mais afastadas das capitais dos estados. A falta dessas ações pelo Poder Executivo faz com que o judiciário tenha que aplicar, majoritariamente, as medidas repressivas, pois os aparatos policial e prisional, por mais insuficientes que possam parecer, já estão prontos para agir. ${ }^{54}$

Nesse contexto, apesar do reconhecimento institucional de que a violência doméstica se trata de um fenômeno que demanda uma ação multifacetada, o aspecto mais impactante de seu enfrentamento passou a ser a intervenção penal operada sobre o agressor.

Como sustenta Marília Montenegro,

O Direito Penal aparece sempre como a "primeira grande solução". É preciso penalizar, criar leis, inserir a figura do crime de violência doméstica para acabar com essa impunidade, como se o Direito Penal trouxesse em si uma fórmula mágica e a criação de um novo tipo penal fosse, ingenuamente, a solução de todos os males sociais. 55

Diante da ausência de interesse estatal para implementar outras políticas públicas menos invasivas e mais eficazes, mas que requerem um investimento financeiro e humano mais intenso, percebe-se que o recurso a leis penais se mostra como uma via aparentemente eficaz para agradar o eleitorado e oferecer uma falsa

\footnotetext{
${ }^{54}$ MONTENEGRO, Marília. Lei Maria da Penha: uma análise criminológico-crítica. Rio de Janeiro: Revan, 2015, $1^{\text {a }}$ ed. p 117

${ }^{55}$ Ibid. p 181.
} 
sensação de segurança às mulheres, através da ilusão de que com o enrijecimento da punição o problema da violência doméstica estaria caminhando para uma solução.

Assim, diante das previsões da Lei 11.340/06 foram implementadas alterações no Código Penal para envolver uma punição mais gravosa aos crimes que envolvessem violência contra a mulher. Sendo o crime de agressão física o que detém maior visibilidade, decidiu-se por acrescentar os $\$ 9^{\circ}$ e $\S 10$ ao art. 129 , que estabelecem ser a violência doméstica uma qualificadora da lesão corporal, com pena de detenção de 3 (três) meses a 3 (três) anos, e também causa de aumento de pena. Ademais, modificou-se o art. 61 do Código para incluir no rol das atenuantes genéricas o cometimento de crime no seio de uma relação doméstica. ${ }^{56}$

As duas mudanças mais polêmicas, porém, foram as decorrentes de seus arts. 16 e 41, que, pela sua complexidade, merecem uma análise mais detalhada.

\subsubsection{A MULHER E SEU DIREITO DE ESCOLHA}

$\mathrm{O}$ art. 16 da Lei assim dispõe:

Art. 16. Nas ações penais públicas condicionadas à representação da ofendida de que trata esta Lei, só será admitida a renúncia à representação perante o juiz, em audiência especialmente designada com tal finalidade, antes do recebimento da denúncia e ouvido o Ministério Público.

Posteriormente, no julgamento da ADI 4.424/ $\mathrm{DF}^{57}$, em que se discutia a constitucionalidade do referido dispositivo, o STF, indevidamente se substituindo ao poder legislativo, determinou que nos crime de lesão contra a mulher no ambiente doméstico a ação penal deveria ser pública incondicionada, pouco importando a extensão da lesão.

\footnotetext{
${ }^{56}$ Art. 61. São circunstâncias que sempre agravam a pena, quando não constituem ou qualificam o crime: (...) II - ter o agente cometido o crime: (...) f ) com abuso de autoridade ou prevalecendo-se de relações domésticas, de coabitação ou de hospitalidade, ou com violência contra a mulher na forma da lei específica.

57 Disponível em: <http://redir.stf.jus.br/paginadorpub/paginador.jsp?docTP=TP\&docID=6393143> último acesso: 17 maio 2018.
} 
O argumento utilizado pelo relator Ministro Marco Aurélio, responsável pela proposta de alteração natureza da ação, foi o de que a vítima de violência doméstica frequentemente acaba por não representar contra o agressor ou afasta a representação anteriormente formalizada, o que permite a reiteração da violência. Diante disso, seria necessária a intervenção estatal desvinculada da vontade da vítima "a fim de não esvaziar a proteção à mulher e não prorrogar o quadro de violência, discriminação e ofensa à dignidade humana".

Para se adequar ao posicionamento do STF, o STJ editou, em 2015, o enunciado sumular $\mathrm{n}^{\circ} 542$, in verbis: A ação penal relativa ao crime de lesão corporal resultante de violência doméstica contra a mulher é pública incondicionada.

Tal modificação precisa ser analisada com cautela. O que se verifica por trás dessa aparente boa intenção do Estado em proteger a mulher em situação de violência, é, justamente, a inferiorização feminina que se pretende combater. Quando o Estado afirma que a mulher não é capaz de decidir por si mesma o que é melhor para a sua vida, está reafirmando a ideologia patriarcal.

Nesse sentido, pertinente a crítica de Maria Lúcia Karam quando aponta que o pronunciamento do STF "negou à mulher a liberdade de escolha, tratando-a como se coisa fosse, submetida à vontade de agentes do Estado que, tutelando-a, pretendem ditar o que autoritariamente pensam que seria o melhor para ela. ${ }^{158}$

Grande parte do movimento feminista, porém, aplaudiu a mudança, sustentando que a decisão de prosseguir ou não com a denúncia não depende exclusivamente da vontade da vítima.

Não há dúvidas de que, de fato, diversos fatores subjetivos e objetivos contribuem para que a mulher desista de seguir em frente com a denúncia. A solução, porém, jamais deveria ser tirar-lhe o poder de decidir sobre sua própria vida, mas sim investigar as causas dessa desistência e combatê-las. 
Nesse sentido, Heleieth Saffioti elenca quatro fatores que contribuiriam para o silenciamento das mulheres: ${ }^{59}$

(i) o vínculo afetivo existente entre vítima e agressor, que faz com que a agredida não deseje a punição do homem nem o seu afastamento dos filhos;

(ii) a dependência de parceiro em sentido amplo, uma vez que, como as mulheres não pertencem a grupos dominantes, parte da sua autodeterminação deriva do relacionamento que estabelece com o homem;

(iii) a ainda existente dependência financeira de muitas mulheres para com seus companheiros, o que faz com que a mulher não tenha condições materiais de arcar com o próprio sustento e o sustento dos filhos; e

(iv) a pressão social e advinda da família estendida (amigos, Igreja) pela preservação do núcleo familiar, tido como algo sagrado e que deve ser mantido a qualquer custo.

Para Elena Larrauri, o maior motivo que leva a mulher a suportar os maus tratos é a dependência econômica. A autora parte do pressuposto que uma mulher que possua recursos para encontrar um emprego, acesso à habitação e possibilidade de sustentar seus filhos está em melhores condições para frear qualquer tipo de agressão que receba de seu companheiro. Na medida em que o sistema de justiça criminal não oferece mecanismos que a ajudem a alcançar essa independência, não deveria parecer estranho, tampouco deveriam ser suscitadas acusações acerca da irracionalidade da mulher, o fato de ela recorrer a esse sistema em casos de extrema urgência e, tão logo o risco se afaste, retirar a denúncia. ${ }^{60}$

\footnotetext{
${ }^{58}$ KARAM, Maria Lúcia. Os paradoxais desejos punitivos de ativistas e movimentos feministas. In: Forum.2015. Disponível em: < https://www.revistaforum.com.br/maria-lucia-karam-os-paradoxaisdesejos-punitivos-de-ativistas-e-movimentos-feministas>

${ }^{59}$ SAFFIOTI, Heleieth I. B. Já se mete a colher em briga de marido e mulher. In: São Paulo em Perspectiva, São Paulo, v. 13, n. 4, p. 87-88, Dezembro de 1999. Disponível em http://www.scielo.br/scielo.php?script=sci_arttext\&pid=S0102-

88391999000400009\&lng=en\&nrm=iso. Acesso realizado em 02 de maio de 2018. p. 87-88.

${ }^{60}$ LARRAURI, Elena. Por qué las mujeres maltratadas retiran las denuncias? In: Mujeres y sistema penal:violencia doméstica. Montevideo: B de F Editorial, 2008, p. 95-132.
} 
Outra razão que levaria a mulher a retirar a denúncia está nos limites da aplicação das medidas de proteção à vítima. Em que pese a importância de sua previsão legal, como o faz a Lei Maria da Penha nos seus arts. 22, 23 e 24, nem sempre as medidas são aplicadas e, quando o são, seu controle de cumprimento pode não ser suficiente, de forma que a vítima fica vulnerável às pressões do agressor.

Assim, o Estado deveria investir na proteção efetiva da mulher, que se sentindo segura, teria liberdade para decidir instaurar ou não um processo penal em relação ao seu agressor. Porém, é muito mais fácil e cômodo simplesmente retirar-lhe seu direito à autodeterminação, atribuindo ao órgão acusatório a legitimidade para mover o processo mesmo que contra a vontade da vítima.

\begin{abstract}
Nesse sentido, é válido o alerta de Maria Lúcia Karam quando diz que
É preciso sempre ter cuidado com mecanismos que, sob o pretexto de tutelar ou proteger determinados grupos de pessoas consideradas mais frágeis ou mais vulneráveis, acabam por inferiorizar tais grupos, acabando por instrumentalizar a materialização de concepções discriminatórias.
\end{abstract}

A proibição de uma conduta que atenta contra a pessoa não pode servir para tolher, ainda que indiretamente, a liberdade dessa mesma pessoa que a norma pretende proteger. A realização de direitos fundamentais evidentemente não convive com a contrariedade aos anseios e aos direitos dos próprios titulares dos bens destinatários da tutela jurídica.

Quando se insiste em acusar da prática de um crime e ameaçar com uma pena o parceiro da mulher, contra a sua vontade, está se subtraindo dela, formalmente dita ofendida, seu direito e seu anseio a livremente se relacionar com aquele parceiro por ela escolhido. Isto significa negar-lhe o direito à liberdade de que é titular, para tratála como se coisa fosse, submetida à vontade de agentes do Estado que, inferiorizandoa e vitimizando-a, pretendem saber o que seria melhor para ela, pretendendo punir o homem com quem ela quer se relacionar — e sua escolha há de ser respeitada, pouco importando se o escolhido é ou não um "agressor" — ou que, pelo menos, não deseja que seja punido. ${ }^{61}$

\footnotetext{
${ }^{61}$ KARAM, Maria Lúcia. Violência de Gênero: o Paradoxal Entusiasmo Pelo Rigor Penal. 2006. In: Boletim do Ibccrim. Disponível em: <https://www.ibccrim.org.br/boletim_editorial/198-168Novembro-2006> último acesso: 10 maio 2018.
} 


\subsubsection{A INAPLICABILIDADE DA LEI $9.099 / 05$}

A Lei Maria da Penha não apenas retirou da mulher seu direito de decidir se quer ou não processar criminalmente seu agressor, como também afastou qualquer possibilidade de aplicação de medidas despenalizadoras, ao dispor, em seu art. 41 que, "[a]os crimes praticados com violência doméstica e familiar contra a mulher, independentemente da pena prevista, não se aplica a Lei $n^{\circ}$ 9.099, de 26 de setembro de 1995."

Sem dúvidas, o Juizado Especial Criminal não era o órgão adequado para acolher as mulheres em situação de violência, por todos os motivos já narrados anteriormente e, assim, o movimento feminista viu como uma grande vitória a inserção desse dispositivo, bem como a possibilidade de criação de Juizados Especiais de Violência Doméstica, com competência civil e penal.

Ocorre que, quando se afastou todas as medias despenalizadoras, afastou-se também a possibilidade de conciliação, que, para muitas mulheres, consistia no principal objetivo quando procuravam ajuda no sistema de justiça. Como adverte Elena Larrauri, clamar pela intervenção do sistema criminal para a proteção das mulheres implica em, no mínimo, estabelecer um direito penal que possa oferecer respostas às diversas demandas que venham a surgir por parte das vítimas, incluindo o desejo de apenas cessar a violência, mas não a relação afetiva entre as partes.

É certo que a conciliação, quando aplicada nos moldes da Lei 9.099/95, era, de fato, danosa para vítima, pois, o operador do direito que guiava a conciliação não era preparado para discutir o problema entre as partes, mas sim para encontrar um culpado e ameaçá-lo com uma provável pena caso não se reconciliasse. Além disso, o JECRIM tem como princípio a celeridade processual, logo essa "conciliação", na prática, acabava sendo uma conversa rápida de 10 minutos em um ambiente penal, sendo inerente que todos os estigmas, medos e anseios da justiça criminal aflorem no momento do ingresso nesse local. 
Assim, segundo Marília Montenegro, uma situação que se repetia muito era a de que o agressor aceitasse a conciliação não pela existência de um consenso com a vítima, mas por medo de ser processado criminalmente. Passada a audiência, o ciclo de violência doméstica se reiniciava. ${ }^{62}$

Acontece que, como bem observa Carmen Hein de Campos, ainda que a aplicação da conciliação realizada do jeito que era fosse, na maioria das vezes, ineficaz, a supressão desse procedimento deixou uma lacuna, pois a maior parte das vítimas de violência doméstica que procura o sistema de justiça não deseja a prisão do seu agressor, seja pelo fato de a vítima ainda nutrir afeto pelo companheiro/pai/irmão, seja pelo fato de não achar que uma pena possa resolver ou equacionar a questão da violência sofrida.

[R]esta perguntar se é possível avançar não apenas a aplicabilidade da Lei, mas, sobretudo, as respostas penais e não penais por ela oferecidas. Sabe-se que a Lei não criou tipo penal novo, mas tampouco ofereceu alternativas às tradicionais respostas penais. Ao contrário, ao impossibilitar a aplicação da conciliação, da transação penal e da suspensão condicional do processo, ela subtraiu essas alternativas jurídicas sem oferecer outras. Se isso foi necessário diante do quadro que se apresentava pela aplicação da Lei 9.099/95, hoje parece ser fundamental construir novas possibilidades. ${ }^{63}$

Nesse sentido, um instrumento que poderia se adequar como uma boa alternativa jurídica seria o oferecimento da mediação como etapa anterior ao processo criminal.

A mediação, que vem sendo muito utilizada na esfera cível, é um procedimento voluntário - tanto o agressor quanto a vítima tem que manifestar seu interesse em participar -, cujo propósito é encontrar uma solução viável e adequada para ambas as partes envolvidas no conflito. É realizada por pessoas capacitadas, que realmente escutam os desejos e necessidades dos dois e que abrem a possibilidade de diálogo entre eles. Nesse contexto, aceitam-se desculpas, assimilam-se responsabilidades, sem qualquer tipo de pressão. As sessões podem se estender por

\footnotetext{
${ }^{62}$ MONTENEGRO, Marília. Lei Maria da Penha: uma análise criminológico-crítica. Rio de Janeiro: Revan, 2015, $1^{\text {a }}$ ed. p. 183
} 
semanas ou até meses, dependendo da vontade das partes. Muitas vezes o conflito é resolvido ali, de modo que não haveria necessidade de se seguir com o processo criminal.

Nos casos em que o ciclo de violência já houvesse se instalado, seria fundamental que o Estado investisse na implantação das políticas de acompanhamento multidisciplinar das vítimas, mulheres e crianças, que precisam ser bem acolhidas, contribuindo para a redução de danos e combatendo a reprodução do mesmo tipo de violência entre as gerações.

Esses são apenas alguns exemplos de alternativas possíveis que o sistema de justiça criminal poderia oferecer se estivesse interessado em atender às expectativas das vítimas que recorrem a ele.

\subsubsection{A EFETIVIDADE DA LEI}

Ainda que seja sensível a necessidade de adoção de medidas a fim de combater a assimetria entre os gêneros e suas consequências (notadamente a violência contra a mulher), mostra-se difícil medir a efetividade da Lei Maria da Penha para além de seu sentido simbólico. A temática em geral se mostrava carente de avaliação estatística em razão da sua significativa subnotificação.

Segundo a pesquisa feita pelo DataSenado em 2013, menos de $40 \%$ das vítimas afirma ter procurado alguma instância de ajuda, seja esta oficial ou não, após a primeira agressão. As demais afirmam não ter procurado ajuda alguma ou então ter buscado auxílio somente a partir da terceira agressão (21\% e 32\% dos casos, respectivamente). ${ }^{64}$

\footnotetext{
${ }^{63}$ CAMPOS, Carmen Hein. Razão e sensibilidade: teoria feminista do direito e Lei Maria da Penha. In: Campos, Carmen Hein de (org.). Lei Maria da Penha comentada em uma perspectiva jurídicofeminista. Rio de Janeiro: Lumen Juris, 2011. p. 9-10.

64 SECRETARIA DE TRANSPARÊNCIA. Violência Doméstica e Familiar Contra a Mulher. DataSenado, Março de 2013, p. $6 . \quad$ Disponível em
} 
A indisponibilidade de dados acerca de violência contra a mulher no meio doméstico faz com que uma das únicas investigações possíveis seja a análise comparativa do número de homicídios femininos ao longo dos anos.

Assim, de acordo com o Mapa da Violência, publicado em 2015, que adotou como principal fonte o Sistema de Informações de Mortalidade da Secretaria de Vigilância em Saúde do Ministério da Saúde, desde 1980, o número de homicídios praticados contra mulheres no País, anualmente, aumentou progressivamente. Era de 2,3\%, o que corresponde a 1353 homicídios por 100 mil habitantes, em 1980, e passou a ser de $4,8 \%$, correspondendo a 4762 homicídios por 100 mil habitantes, em 2013. ${ }^{65}$

Curiosamente, observou-se uma redução na porcentagem de homicídios apenas entre os anos de $2006(4,2 \%)$ e 2007 (3,9\%), justamente o período imediato à entrada em vigor da Lei Maria da Penha. Tal constatação leva a crer que o caráter repressivo da lei teve efeitos limitados e temporais.

Pode-se afirmar que, em 2013, houve 13 homicídios femininos diários no Brasil. Esse índice é alarmante, especialmente, quando comparado com outros 83 países pesquisados pela Organização Mundial da Saúde. O Brasil desponta em quinto lugar no número de homicídios de mulheres, atrás apenas de El Salvador, Colômbia, Guatemala e Federação Russa. ${ }^{66}$

Isso indica que, apesar do incremento dos mecanismos de repressão, os casos de violência contra a mulher não estão sofrendo redução. Ainda, assim, continua-se insistindo no Direito Penal como principal instrumento de combate à violência doméstica.

No próximo capítulo tentar-se-á demonstrar como a Lei Maria da Penha, ao retirar a autonomia da mulher, impor um processo penal contra a sua vontade e

http://www.senado.gov.br/noticias/datasenado/pdf/datasenado/DataSenado-Pesquisa-

Violencia_Domestica_contra_a_Mulher_2013.pdf. Último acesso: 10 maio 2018

${ }^{65}$ WAISELFISZ, Julio Jacobo. Mapa da Violência 2015: homicídio de mulheres no Brasil. Brasília: FRACSO, $2015 . \quad$ Disponível em:<http://www.mapadaviolencia.org.br/pdf2015/MapaViolencia_2015_mulheres.pdf > Último acesso em 20 maio 2018. 
ignorar suas reais demandas, pode estar, inclusive, gerando um efeito contrário do que se pretendia, contribuindo ainda mais para a perpetuação do ciclo de violência doméstica.

${ }^{66}$ WAISELFISZ, Julio Jacobo. Mapa da Violência 2015: homicídio de mulheres no Brasil. Brasília: FRACSO, 2015, p. 11, 13 e 28. 


\section{A (IN)EFICÁCIA DO DIREITO PENAL NO COMBATE À VIOLÊNCIA DOMÉSTICA CONTRA A MULHER}

\subsection{A CONSTRUÇÃO DE UMA CRIMINOLOGIA CRÍTICA}

Este trabalho foi proposto a partir da elaboração de seguinte questão: seria o instrumento penal meio idôneo para o enfrentamento da violência de gênero, em especial aquela que ocorre no ambiente doméstico ou, ao contrário, acaba por contribuir com a perpetuação de práticas de controle social da mulher?

Para respondê-la, torna-se necessário, antes de tudo, analisar em que consiste esse processo de criminalização ao qual grande parte do movimento feminista está recorrendo.

Pois bem. Como mencionado no primeiro capítulo, a criminologia tradicional (positivista), que teve como fundador o médico italiano Césare Lombrso, sustentava que a etiologia do crime era essencialmente individual, sem qualquer relação com as condições sociais e contextuais nas quais o indivíduo estivesse inserido. Assim, o objeto de estudo era o próprio delinquente; buscava-se nele as causas naturais para seu comportamento desviante.

Entendia-se que uma vez identificadas as características físicas, biológicas e psíquicas determinantes para a delinquência, seria possível encontrar remédios para combatê-la. Surgem, assim, as estratégias de correcionalismo, que se revestem de características curativas, reeducativas e ressocializadoras. A pena ganha razões para se expandir. Essa talvez seja uma das principais permanências da escola do positivismo até hoje. ${ }^{67}$

${ }^{67}$ BATISTA, Vera Malaguti. Introdução Crítica à Criminologia Brasileira. $2^{\mathrm{a}}$ ed. Rio de Janeiro: Revan, 2011, p.45-46. 
A principal obra dessa corrente é L'uomo delinquente (" $\mathrm{O}$ homem delinquente"), onde Lombroso descreve o criminoso nato (que correspondia ao delinquente violento ${ }^{68}$. Segundo o autor, este seria um homem atávico, degenerado, marcado pela transmissão hereditária do mal, e que, portanto, já nasceria com uma pré-disposição ao crime. Esse saber se baseou na análise das pessoas que se encontravam encarceradas. Como a grande maioria eram homens negros, deduziu-se que estes corresponderiam à "estética do mal".

Observe-se que em nenhum momento se questionava o fato de dentro da prisão haver inocentes, nem de fora dela haver criminosos desconhecidos. Da mesma forma não se refletia a respeito da razão de determinada conduta ser criminalizada, pois se entendia o delito como uma entidade ontológica pré-constituída.

A concepção de crime natural sofre um golpe mortal por volta da década de 1960, com o surgimento de um novo paradigma criminológico: o labeling approach (ou teoria do etiquetamento social). Trata-se de um novo marco epistemológico, no qual o foco do estudo da criminalidade deixa de ser o criminoso e passa a ser a criminalização.

Nas palavras de Vera Andrade,

o labeling parte dos conceitos de "conduta desviada" e "reação social", como termos reciprocamente interdependentes, para formular sua tese central: a de que o desvio e a criminalidade não é uma qualidade intrínseca da conduta ou uma entidade ontológica preconstituída à reação social e penal, mas uma qualidade (etiqueta) atribuída a determinados sujeitos através de complexos processos de interação social; isto é, de processos formais e informais de definição e seleção. ${ }^{69}$

Em outras palavras, esse novo paradigma parte da premissa de que a criminalidade não existe na natureza; ela é fruto de uma construção social, pautada em critérios seletivos e discriminatórios de instituições oficiais e não oficiais. Por

\footnotetext{
68 Para além do criminoso nato, Lombroso classificou os demais criminosos como ocasionais, passionais, loucos morais e epiléticos.

${ }_{69}$ ANDRADE, Vera Regina Pereira de. Do paradigma etiológico ao paradigma da reação social: mudança e permanência de paradigmas criminológicos na ciência e no senso comum. Florianópolis: Sequência. 1995, p. 28.
} 
essa perspectiva, passa-se a entender que uma conduta não é criminal em si mesma nem seu autor um criminoso nato. O crime só existe depois de ser definido com tal.

\section{Becker explica:}

os grupos sociais criam o desvio ao fazerem as regras cuja infração constitui o desvio e aplicar ditas regras a certas pessoas em particular e qualificá-las de marginais (estranhos). Desde este ponto de vista, o desvio não é uma qualidade do ato cometido pela pessoa, senão uma consequência da aplicação que os outros fazem das regras e sanções para um "ofensor". O desviante é uma pessoa a quem se pode aplicar com êxito dita qualificação (etiqueta); a conduta desviante é a conduta assim chamada pela gente. ${ }^{70}$

Nesse sentido, o sistema penal não se reduz ao complexo estático das normas penais; pelo contrário, ele é um processo articulado e dinâmico, ao qual concorrem todas as agências de controle social formal e informal. A norma aparece aqui como regra do jogo, e não como valor. ${ }^{71}$ Tanto é assim, que o adultério antes era considerado crime, até que deixou de ser.

A criminalidade se revela, assim, como um status atribuído a determinados indivíduos mediante um processo seletivo que se opera em duas etapas. A primeira (criminalização primária) corresponde ao processo de elaboração e promulgação de lei que irá definir determinada conduta como crime. Há, nesse momento, uma seletividade abstrata onde aqueles que possuem maior poder de influência política direcionam o sistema penal para a tipificação dos desvios conforme seus interesses. ${ }^{72}$

A segunda etapa (criminalização secundária), por sua vez, é verificada através da ação punitiva exercida sobre as pessoas concretas, por meio dos policiais, membros do Ministério Público, magistrados e agentes penitenciários. Eles não investigam, julgam e condenam de forma isonômica todas as pessoas que podem ter praticado a conduta que foi definida como crime na etapa primária. Em verdade, eles selecionam, dentre todos os autores da infração, aqueles que serão etiquetados e

\footnotetext{
70 BECKER, H. Los extraños. Buenos Aires: Tiempo Contemporáneo, 1971, p.19.

71 BATISTA, Vera Malaguti. Introdução Crítica à Criminologia Brasileira.Rio de Janeiro: Revan, 2011.

72 MENDES, Soraia de Rosa.Criminologia feminista: novos paradigmas. São Paulo: Saraiva. $2^{\mathrm{a}}$ ed. 2017. p. 59
} 
estigmatizados como criminosos. Há, assim, uma verdadeira filtragem entre a criminalidade latente e a criminalidade perseguida.

O fato de haver uma seleção no sistema penal indica que a criminalidade não é um comportamento de uma minoria bárbara e perigosa. A maioria das pessoas já cometeu alguma conduta definida como crime, porém alguns indivíduos são etiquetados por corresponderem ao estereótipo de delinquente e outros não.

Segundo Thula Pires:

O sistema penal seria, então, guiado por estereótipos criados socialmente e reproduzidos institucionalmente - notadamente pelos órgãos de repressão - de forma a garantir a aplicação seletiva de normas penais. Partindo do pressuposto de que as condutas delitivas são cometidas por pessoas de todos os grupos sociais, o olhar que se faz das estatísticas do sistema penal, ao invés de sacralizar a ideia de que o contingente nela representado englobaria o perfil natural do delinquente, serve apenas para identificar o estereótipo escolhido socialmente para figurar na condição marginal de desviado, controlado, encarcerado e desumanizado. ${ }^{73}$

Sem dúvidas, o trabalho de Sutherland sobre os crimes de colarinho branco ${ }^{74}$ até então ignorados -, foi fundamental para esses estudos deslegitimadores do sistema penal. Ao demonstrar que pessoas respeitáveis e de alta posição social, também cometiam crimes no exercício de suas ocupações, restou nítida a distorção estatística que produz aquilo que Alessandro Baratta chama de "quadro falso de distribuição de criminalidade", concentrada sempre nos estratos mais pobres da sociedade.

Hassemer chama a atenção para o fato de que o processo de criminalização e estigmatização não ocorrem à margem ou mesmo contra os processos gerais de etiquetamento que já são realizados pelo controle social informal, como, por exemplo, a igreja, a família e escola, que estigmatizam determinadas pessoas como "pecadoras", "ovelhas-negras", "rebeldes" etc. ${ }^{75}$

\footnotetext{
${ }^{73}$ PIRES, Thula Rafaela de Oliveira. Criminalização do Racismo: entre política de reconhecimento e meio de legitimação do controle social sobre os negros. $1^{a}$ ed. Brasília: Brado Negro 2016, p. 239.

${ }^{74}$ SUTHERLAND, Edwin Hardin. White Collar Crime. New York: Dryden Press, 1949.

${ }^{75}$ HASSEMER, Winfried. Fundamentos del derecho penal. Tradução por Francisco Muñoz Conde e Luis Arroyo Zapatero. Barcelona: Bosch, 1984., p.37
} 
Com efeito, percebe-se que as instituições que participam do processo de criminalização seletiva não podem ser vistas de forma isolada, uma vez que integram um sistema mais amplo de controle social global da conduta desviada. O processo de criminalização passa a ser compreendido, assim, como sendo intimamente ligado às relações de poder encontradas no meio social, que determinam a desigual distribuição dos riscos e das imunidades do sistema de justiça criminal.

Essa ruptura, fundamental para a constituição de uma criminologia crítica, produziu um chamado para estudos e pesquisas sobre os sistemas penais. A pergunta não é mais "quem é criminoso?", mas sim "quem é definido como criminoso?" e "quem tem o poder de definir?". ${ }^{76}$

A partir daí distintas correntes, que se identificam sob o rótulo "criminologia crítica", passaram a projetar inúmeras ações no campo político, em sua grande maioria voltadas à construção das hipóteses de criminalização e superação da forma carcerária de penas.

Influenciada principalmente pelo marxismo, a criminologia crítica traz uma interpretação materialista e econômico-política do desvio dos comportamentos socialmente negativos e da criminalização.

Por essa perspectiva, o processo de criminalização passa a ser compreendido como um mecanismo voltado para regular as condutas e atividades que se dão no domínio público das relações de trabalho produtivo, de forma a manter a própria ordem social que o garante. Assim, aqueles que estão à margem da produção econômica tem uma maior probabilidade de serem etiquetados como criminosos.

\section{Como explica Thula Pires ${ }^{77}$,}

a criação da figura do delinquente está diretamente relacionada com os sujeitos que se pretende excluir do mercado de trabalho, atuando o sistema penal como principal órgão de controle do contingente de excluídos gerado pela seletividade do modelo econômico

\footnotetext{
76 BARATTA, Alessandro. Criminologia crítica y crítica del Derecho penal: introducción a la Sociologia jurídicopenal. Tradução por Alvaro Bunster. México: Siglo veintiuno, 199, p. 87

${ }^{77}$ PIRES, Thula Rafaela de Oliveira. Criminalização do Racismo: entre política de reconhecimento e meio de legitimação do controle social sobre os negros.Brasília: Brado Negro 2016, p. 240.
} 
capitalista; o mesmo ocorrendo com a figura do delito, definida não por ser uma violência a priori, mas por ser uma ação inadequada à manutenção dos interesses das classes dominantes.

Pode-se dizer, assim, que o sistema penal é uma engrenagem formada pelo Poder Legislativo, Judiciário, Ministério Público, Polícia, sistema carcerário e demais agências formais de controle, que orientam suas ações para a retirada do convívio social dos membros considerados "fora do lugar". Nesse sentido, a prisão seria, praticamente, um depósito para os inadaptados.

\section{Segundo Maria Lúcia Karam ${ }^{78}$,}

A imposição da pena não passa de pura manifestação de poder, destinada a manter e reproduzir os valores e interesses dominantes em uma dada sociedade. Para isso, não é necessário nem funcional acabar com a criminalidade de qualquer natureza e, muito menos, fazer recair a punição sobre todos os autores de crimes, sendo, ao contrário, imperativa a individualização de apenas alguns deles, para que, exemplarmente identificados como criminosos, emprestem sua imagem à personalização da figura do mau, do inimigo, do perigoso, assim possibilitando a simultânea e conveniente ocultação dos perigos e dos males que sustentam a estrutura de dominação e poder.

Além da seletividade baseada na classe social, alguns representantes da criminologia agregam outros elementos às suas análises, entre eles os componentes de gênero e patriarcado.

Na criminalização primária, a cultura do patriarcado aparece, por exemplo, ao etiquetar como crime a prática do aborto, conduta esta que representa, em uma análise mais profunda, o poder da mulher sobre o seu próprio corpo e a sua negação ao papel social de mãe. Criminalizar essa conduta, é uma forma de manter a ordem androcêntrica.

$\mathrm{Na}$ criminalização secundária, por sua vez, pode-se verificar esses componentes na seleção de quem será efetivamente etiquetado como estuprador. Sabe-se, hoje, que os crimes sexuais são condutas majoritárias e ubíquas e não de uma minoria anormal. Não acontecem apenas na rua, por estranhos; mas,

\footnotetext{
78 KARAM, Maria Lúcia. A esquerda punitiva. In: Empório do Direito. 2015. Disponível em: <http://emporiododireito.com.br/leitura/a-esquerda-punitiva-1508702858> último acesso: 28 maio 2018.
} 
principalmente, em locais de confiança, por pais, irmãos, amigos, maridos, companheiros ou namorados. ${ }^{79}$

Nesse sentido, Salo de Carvalho:

Com os estudos sobre a violência de gênero, o criminoso não apenas deixa de ser um estranho que emerge ao acaso no espaço público, viola o contrato social e revive o estado de barbárie, como é apresentado como alguém familiar, demasiado íntimo. O tipo-ideal do criminoso feio e abjeto, produzido pela estética criminológica positivista, é desestabilizado. Isto porque será o 'príncipe encantado', repositório do sonho apolíneo de felicidade presente no imaginário coletivo, o sujeito capaz das mais radicais formas de violência. A investigação feminista sobre a recorrência dos atos de violência física e sexual praticada no âmbito doméstico - situação pouco narrada pela literatura infantil nos contos de fada - presentifica o crime no lar, último refúgio de segurança imaginado por um modelo de sociedade embriagado pela promessa de erradicação da criminalidade. ${ }^{80}$

Ocorre que esses homens, que pertencem ao mesmo círculo social/afetivo da mulher, não correspondem, em absoluto, ao estereótipo de estupradores e por isso dificilmente são condenados. É mais fácil para a justiça criminal reconhecer que houve estupro quando o seu autor é uma pessoa estranha à vítima, e, preferencialmente, de baixo estrato social. ${ }^{81}$

Somando-se isso à seletividade das vítimas em razão da lógica da honestidade, analisada no primeiro capítulo, em que as mulheres são divididas de acordo com a sua reputação/moral sexual, temos como resultado uma justiça que absolve muito mais do que condena nos crimes sexuais. "A regra, na conduta de estupro - seguindo a lógica do sistema - é a impunidade, e a condenação em casos limites. ${ }^{182}$

\subsection{DIREITO PENAL MÍNIMO X DIREITO PENAL PARA AS MINORIAS}

\footnotetext{
79 ANDRADE, Vera Regina Pereira de. A Soberania Patriarcal: O Sistema de Justiça Criminal no Tratamento da Violência Sexual Contra a Mulher.In: Doutrina Brasiliera, 2009, p. 81

80 CARVALHO, Salo de. Sobre as possibilidades de uma criminologia queer. In: Sistema Penal \& Violência revista do Programa de Pós-Graduação em Ciências Criminais da PUCRS. 2012, p. 160.

${ }^{81}$ ANDRADE, Vera Regina Pereira de. Op. cit. p. 97.

${ }^{82}$ ANDRADE, Vera Regina Pereira de. Op. cit. p. 95
} 
Diante dessa deslegitimação do sistema criminal apresentada pela criminologia crítica, surgiram as tendências minimalistas do Direito Penal, que entendem que, sendo este o maior instrumento de poder das classes dominantes, deve ser utilizado com parcimônia, como última ratio, somente "quando os demais ramos do Direito revelarem-se incapazes de dar a tutela devida a bens relevantes na vida do indivíduo e da própria sociedade. ${ }^{183}$

Assim, dever-se-ia recorrer a ele apenas quando já esgotados todos os meios extrapenais de controle social, até mesmo porque as prisões do Brasil não são feitas para ressocializar/reeducar ninguém. A prisão só ensina a viver na prisão. ${ }^{84}$ Não há como as pessoas adquirirem valores próprios da convivência social em um estabelecimento prisional, que as isolam da sociedade e as tratam de forma extremamente desumana.

A lógica por trás dos castigos penais é, principalmente, a da retribuição, uma forma de vingança institucionalizada, que prega que a ordem jurídica atingida pela conduta criminosa somente pode ser restaurada por meio da imposição de um mal àquele que a atingiu ${ }^{85}$ Não se pode perder de vista, porém, que ao cercear as liberdades individuais, as sanções impõem uma penalização que, muitas vezes, transcende o espaço temporal da pena e se prolonga para toda uma existência, limitando oportunidades e não raramente marginalizando aquele que passa pelo sistema penal, sendo certo que este ficará estigmatizado pelo resto da vida.

É preciso, assim, muita cautela ao se recorrer a esse sistema tão danoso para não o banalizar. Será que, por exemplo, alguém que pratica assédio sexual realmente precisa/merece passar por todo esse sofrimento? Sem dúvidas tal conduta deve ser rechaçada e devidamente punida, mas será que uma indenização na esfera cível,

\footnotetext{
${ }^{83}$ BITENCOURT, Cezar Roberto. Tratado de Direito Penal - parte geral. $13^{\mathrm{a}}$ Edição. São Paulo: Saraiva, 2008, p. 13 e 14.

${ }^{84}$ SANTOS, Juarez Cirini dos. A criminologia radical. $2^{\mathrm{a}}$ ed. Curitiba: Lumem Iuris: Rio de Janeiro: Forense, 2006, p. 80 e ss.

${ }^{85}$ HASSEMER, Winfried. Introdução aos fundamentos do direito penal. Traduzido da $2^{\mathrm{a}}$ edição alemã. Porto Alegre: Sérgio Antonio Fabris Editor, 2005, p. 370; ROXIN, op. cit., 2008, p. 17.
} 
trabalhos comunitários ou a participação em centros de educação não seriam medidas suficientes e muito mais efetivas?

Há quem sustente ter a pena uma função preventiva, uma vez que a norma penal poderia operar como uma espécie de coação psicológica à sociedade. Com medo do castigo, os indivíduos deixariam de cometer crimes. A grande falha dessa teoria é ter como pressuposto uma racionalidade humana que levaria todos os cidadãos a ponderarem que a prática delitiva não é compensatória, em razão do alto preço vinculado a ela. Ignora, porém, que para muitas pessoas impera a racionalidade do risco: ainda que a resposta penal seja gravosa, há a possibilidade de o crime permanecer impune, portanto, pode valer a pena arriscar. ${ }^{86}$

Nesse sentido, no tocante à política criminal, as sanções penais devem ter sua aplicabilidade reduzida ao mínimo possível por dois principais motivos: (i) porque a aplicação de uma pena implica necessariamente no prévio cometimento do delito, o que significa que houve falha nas iniciativas preventivas; (ii) porque os castigos impostos pelo Direito Penal não apenas são desumanizantes, dadas as condições dos cárceres no Brasil, como também são, por si só, estigmatizantes, como o é o processo penal precedente à execução.

Assim, conforme Maurício Zanoide de Moraes,

Boa política criminal é aquela que, examinando as causas do crime, atua de modo a que ele não mais surja. Péssima política criminal é aquela que se limita à estruturação de um amplo e exauriente aparato legal punitivo, isto porque, não há segurança pública em se punir o crime, pois, para que ele seja punido, é necessária sua ocorrência. $^{87}$

86 COUTO, Maria Cláudia Girotto. Lei Maria da Penha e Princípio da Subsidiariedade. São Paulo. 2016. Dissertação de mestrado defendida na USP, p.94.

${ }^{87}$ Sobre o processo penal, o autor observa que este já é uma pena que se impõe ao acusado, sendo um mal em si mesmo: "[p]une-se, portanto, com o processo, muitos inocente". MORAES, Maurício Zanoide de. "Política Criminal, Constituição e Processo Penal: razões da caminhada brasileira para a institucionalização do caos" in Revista da Faculdade de Direito da Universidade de São Paulo. V. 101, jan-dez 2006, p. 409 e 415. 
Contrariando essa tendência do minimalismo penal, observa-se uma crescente demanda pela expansão do sistema penal por parte dos grupos historicamente marginalizados. São minorias representativas que sempre sofreram com a opressão desse sistema (mulheres, negros, LGBTTI), mas que acreditam que em um possível uso alternativo do mesmo. Por essa perspectiva, o Direito Penal poderia ser utilizado não para manter as relações de dominação existentes, mas sim como uma política de reconhecimento e emancipação desses grupos, através de sua função simbólica.

Esse recurso à criminalização como política de reconhecimento baseia-se na crença de que o Estado, ao legislar, teria a força de inverter a simbologia já existente na sociedade, atuando como uma forma de persuasão sobre os indivíduos para que eles obedeçam a uma conduta mínima de comportamento, sob pena de serem taxados de delinquentes. No caso específico da violência doméstica, acredita-se que o Direito Penal poderia inverter o poder onipotente do marido sobre a mulher, trazendo à tona o equilíbrio na relação doméstica. ${ }^{88}$

Segundo Thula Pires,

Alguns grupos sociais vão rechaçar o aumento do poder punitivo do Estado e a mistura entre castigo e prevenção do delito, ao mesmo tempo em que apostam na utilização da pena como mensagem. Criminalizar o desrespeito representa a possibilidade de trazer para a esfera pública conflitos que foram secularmente subsumidos à dimensão privada e, com isso, vistos como problemas meramente pontuais e não como socialmente estruturais, e, com isso, promover a discussão pública acerca do caráter nocivo dessas atitudes na conformação sadia de identidades individuais e coletivas. ${ }^{89}$

Marília Montenegro lembra, porém, que o Direito Penal simbólico não gera efeitos protetivos concretos e, geralmente, é utilizado para conter manifestações de grupos sociais ou políticos que desejam repudiar determinadas atitudes consideradas lesivas à sua existência ou aos seus interesses. Ao que Roxin acrescenta: "comumente não se almeja mais do que acalmar eleitores, dando-se, através de leis presivelmente

\footnotetext{
${ }^{88}$ MONTENEGRO, Marília. Lei Maria da Penha: uma análise criminológico-crítica. Rio de Janeiro: Revan, 2015, $1^{\text {a }}$ ed.

${ }^{89}$ PIRES, Thula Rafaela de Oliveira. Criminalização do Racismo: entre política de reconhecimento e meio de legitimação do controle social sobre os negros.Brasília: Brado Negro 2016, p. 226.
} 
ineficazes, a impressão de que está fazendo algo para combater ações e situações indesejadas. ${ }^{190}$

O uso simbólico da legislação pode ser uma estratégia interessante para quem está no poder responder ao grupo político descontente, sem alterar significativamente sua realidade, uma vez que tem como objetivo fomentar a confiança do indivíduo no Estado, ou em determinado governo, construindo uma aparente solução dos problemas sociais, ao mesmo tempo em que obstrui o caminho para seu real enfrentamento. ${ }^{91}$

Nilo Batista é outro crítico da utilização do Direito Penal como meio de harmonizar conflitos sociais por considerá-la uma estratégia de silenciamento de lutas. O crescimento do alcance penal representaria uma dimensão simbólica do aumento da vigilância física e política do Estado sobre os cidadãos, ocultando o debate sobre as mais variadas opressões. ${ }^{92}$

$\mathrm{O}$ autor destaca, ainda, o papel que a mídia exerce na legitimação desse discurso criminalizador, em que o sistema penal aparece como meio próprio para a contenção de conflitos sociais. Segundo Batista, todo conhecimento produzido nas universidades por estudiosos renomados a respeito da violência institucional das prisões, seus efeitos negativos sobre o indivíduo e o fracasso das ideologias prevencionistas é escondido. Em contrapartida, ganham espaço nos telejornais de maiores audiência, os discursos vazios dos "especialistas de tudo" os quais reduzem a complexidade dos conflitos ao binômio delito-pena e tentam convencer os espectadores que a única opção que resta ao Estado é o poder de punir e criminalizar. $^{93}$

A narrativa sensacionalista da história da vítima apresentada na televisão desperta os medos e a ira dos telespectadores, consequentemente surge um desejo de

\footnotetext{
${ }^{90}$ ROXIN, Claus. Estudos de direito penal. Trad. Luís Greco. Rio de Janeiro:Renovar, 2006, p. 47.

${ }^{91}$ PIRES, Thula Rafaela de Oliveira. Op. cit. p. 253.

92 BATISTA, Nilo. Só Carolina não viu - Violência doméstica e políticas criminais no Brasil. In Jornal do Conselho Regional de Psicologia, ano 5, Rio de Janeiro, mar/2008, p. 7

${ }^{93}$ BATISTA, Nilo. Mídia e sistema penal no capitalismo tardio. Discursos Sediciosos: crime, direito e sociedade, Rio de Janeiro, ano 7, $\mathrm{n}^{\circ} 12$, 2002, p. 274-276.
} 
vingança por parte de toda a sociedade, que também se sente vitimizada com um ato de tamanha violência. O sensacionalismo é utilizado através de instrumentos dramáticos e estratégias sofisticadas para a promoção da insegurança e propagação das medidas de caráter punitivo, de preferência a pena privativa de liberdade, como a principal forma de combate à criminalidade. ${ }^{94}$

A mídia, porém, superficializa as realidades sociais e distorce o modo de enxergá-las, de sorte que a essência dos problemas passa a ser ignorada. Um dos maiores problemas de se recorrer ao Sistema Penal como meio de proteção contra uma discriminação é que este trabalha apenas com uma pequena parte da violência, ignorando-a em suas diversas formas. Alessandro Baratta utiliza o conceito de violência estrutural como uma forma geral de violência que costuma originar, direta ou indiretamente, várias outras formas de violência.

Segundo o autor:

[.... podemos distinguir estas outras formas, segundo o agente, em "violência individual", quando o agente é o indivíduo"; "violência de grupo", quando o agente é um grupo social, que por sua vez se serve de indivíduos particulares: pertence a este tipo de violência aquela realizada por grupos paramilitares. Além disso, podemos falar de "violência institucional", quando o agente é um órgão do Estado, um governo, o exército ou a polícia. A violência institucional pode ter forma legal, ou seja, de acordo com as leis vigentes num Estado ou, como acontece em muitos casos, ilegais. Ainda destaca a "violência internacional", quando o agente é a administração de um Estado, que se dirige em determinadas ações através de órgãos próprios ou de agentes mantidos por aquela, contra o governo e o povo de outro. ${ }^{95 "}$

Há o receio de que a penalização das condutas que representem ataques aos direitos humanos se travista de iniciativa pessoal ou individualizada de afronta, o que, segundo Maria Lúcia Karam, "maquiaria toda a carga cultural por trás de opressões

\footnotetext{
${ }^{94}$ Sobre a televisão como forma de propagação do cárcere conferir: MATHEIESEN, Thomas. Juicio a la prisón: uma evaluación crítica. Trad. Mario Coriolano y Amanda Zamuner. Buenos Aires: Ediar, 2003, p. 302-309.

95 KARAM, Maria Lúcia. Direitos Humanos: entre a violência estrutural e a violência penal. Fascículos de ciências penais. Porto Alegre, v. 6, n² 2, p. 44-61, abr/jun, 1993, p. 47-48.
} 
a grupos como negros, indígenas, mulheres, homossexuais, transexuais, entre outros."

Pela perspectiva de Karam, é um erro considerar que o Direito Penal possa ser convertido em uma via idônea de ação estatal pelo simples fato de agora ter como bens jurídicos tutelados demandas oriundas de grupos historicamente vulnerabilizados:

Essa expansão faria com que as penas recaíssem sobre os mesmos personagens subalternos de sempre, já que a seletividade do sistema persistiria e os segmentos mais frágeis em termos de mobilização política (e condições financeiras) continuariam a representar o foco da repressão penal. ${ }^{96}$

Segundo a autora, ao invés de se promover reflexões transformadoras e implementar políticas públicas que realmente possam acabar com a violência estrutural, o Estado, ao individualizá-la, busca um bode expiatório para que a sociedade possa nele depositar sua reprovação pelo desvio social cometido, mantendo-se intacta a violência estrutural.

Thula Pires, por sua vez, faz uma importante ponderação que merece ser refletida: para quem mesmo denunciando as relações de dominação-opressão da sociedade está acostumado aos espaços de poder deve ser mesmo muito frustrante ver um grupo social apostar suas lutadas fichas em uma política pública simbólica e incapaz de trazer transformações efetivas e diretas no combate à discriminação. No entanto, para quem foi objetificado(a) e invisibilizado(a) por séculos, uma medida que coloca em pauta a crueldade do racismo/machismo/homofobia, mesmo com esse limitado efeito simbólico, representa uma conquista bastante significativa. "As lutas sociais são travadas com as armas que se têm em cada momento histórico. ${ }^{.197}$

Assim, é preciso reconhecer a importância que esse efeito simbólico teve para esses grupos que sempre foram invisíveis aos olhos da proteção estatal. O que não se

\footnotetext{
96 KARAM, Maria Lúcia. A esquerda punitiva. In: Empório do Direito. 2015. Disponível em: <http://emporiododireito.com.br/leitura/a-esquerda-punitiva-1508702858> último acesso: 28 maio 2018.

${ }^{97}$ PIRES, Thula Rafaela de Oliveira. Criminalização do Racismo: entre política de reconhecimento e meio de legitimação do controle social sobre os negros.Brasília: Brado Negro 2016, p. 232.
} 
pode fazer, em hipótese alguma, é superestimar o mesmo, ignorando suas limitações vinculadas diretamente ao seu caráter seletivo, excludente, elitista e machista. Nenhuma minoria pode depositar toda a sua militância nesse ramo do direito, esperando que uma vez declarada a conduta como criminosa, ela deixe de acontecer, pois não é o Direito Penal que promoverá isso. Combater - seletivamente - as consequências sem o enfrentamento adequado das causas é perder o comprometimento com a luta.

\subsection{O DIREITO PENAL COMO RESPOSTA À VIOLÊNCIA DOMÉSTICA}

No tópico anterior foi abordado o uso simbólico do Direito Penal por grupos historicamente marginalizados, dentre os quais destacam-se as mulheres. Na luta feminista contra a discriminação de gênero a inclusão da qualificadora do feminicídio, por exemplo, pode ser considerada uma importante conquista simbólica para o movimento, desde que, todas as mulheres tenham consciência de que essa luta não pode se dar apenas na esfera penal, necessitando ser acompanhada de propostas afirmativas positivas de desconstrução de estigmas e de valorização feminina.

Quando se trata especificamente da violência doméstica, porém, a coisa muda de figura. $\mathrm{O}$ tratamento dado à violência doméstica no Brasil hoje, pela Lei Maria da Penha, não apenas é ineficaz na proteção das mulheres, como acaba gerando o efeito contrário do pretendido, contribuindo para a manutenção da mulher no ciclo de violência.

Conforme narrado no segundo capítulo, a Lei Maria da Penha surgiu no cenário jurídico nacional sob forte pressão política, tanto interna quanto externa. Nesse contexto, os meios de comunicação utilizaram-se de um caso extremo de violência doméstica, como o de Maria da Penha Maia Fernandes, para fomentar e legitimar a necessidade de um maior rigor punitivo para os agressores. 
Como observa Marília Montenegro, o fato da lei 11.340/06 ter recebido o nome dessa mulher específica tirou a sua impessoalidade e fez com que qualquer infração penal que caracterizasse uma violência doméstica fosse sempre associada à violência sofrida por Maria da Penha, como também toda vítima de violência de gênero fosse comparada à sua imagem e semelhança. ${ }^{98} \mathrm{~A}$ autora usa como exemplo o livro de Maria Berenice Dias sobre a lei em comento, no qual a mesma dedica a obra à "todas as Marias da Penha deste país, violadas por seus homens e violentadas pela justiça" ${ }^{\prime \prime 9}$

Montenegro continua sua crítica sustentando que, em decorrência disso passou-se a reinar no intelecto social a ideia de que, em geral, o crime cometido contra a mulher no ambiente doméstico é da mesma espécie que o cometido como Maria da Penha, ou seja, um crime sórdido, cruel e gravíssimo, o que não corresponde à realidade ${ }^{100}$. Outrossim, transmitiu-se a falsa ideia de que, tal como Maria da Penha, todas as mulheres em situação de violência desejam, a todo custo, a punição de seus algozes, o que também não é verdade. Casos como o de Maria da Penha são exceções e não regra no dia-a-dia.

Para comprovar sua tese, a autora passou anos pesquisando as consequências da aplicabilidade da Lei 9.099/95 e, posteriormente, da Lei 11.340/06 (Lei Maria da Penha) no Recife, e pode constatar que, em casos de conflitos domésticos, especialmente os que não apresentam elevada gravidade, a aplicação do Direito Penal é quase sempre desastrosa.

Isso porque público-alvo do sistema prisional são as pessoas que cometem crimes patrimoniais, especialmente o furto e o roubo, e os crimes que envolvem

${ }_{98}$ MONTENEGRO, Marília. Lei Maria da Penha: uma análise criminológico-crítica. Rio de Janeiro: Revan, 2015, $1^{\mathrm{a}}$ ed. p 216.

${ }^{99}$ DIAS, Maria Berenice. A lei Maria da Penha na justiça. São Paulo: Revista dos Tribunais, 2007. p.5

100 Carmem Hein de Campos e Salo de Carvalho, com base no Relatório Anual do CNJ (2010) e em registros do Ministério Público do Rio Grande do Sul, constataram que os crimes mais praticados contra as mulheres no contexto de violência doméstica e familiar são as lesões corporais leves e a ameaça. 
tráfico ilícito de entorpecentes. Nesses casos, ou a vítima não conhece o agressor, ou não existem vítimas determinadas.

Quanto maior o distanciamento entre as partes envolvidas no conflito, menor é o envolvimento e a compreensão da dor da aplicação da pena. A situação é totalmente diferente quando existe um vínculo entre as partes, pois, nesses casos, mais facilmente se compreendem os efeitos da pena e a estigmatização por essa produzida. $^{101}$

Nos casos de violência doméstica, a vítima passa a ter a real ideia das consequências negativas da prisão na vida daquele homem, uma vez que ela é, geralmente, a primeira pessoa que vai visitá-lo no sistema prisional. Ressalte-se que não se trata de qualquer homem. O homem que está sendo encarcerado é seu irmão, seu pai, o pai dos seus filhos, (ex) companheiro, alguém com o qual a mulher possui ou já possuiu uma relação de afeto.

Segundo as pesquisas da autora, a intervenção estereotipada do Direito Penal promove uma dupla vitimização da mulher, na medida em que não leva em conta a sua singularidade, os seus laços com o agressor. O sistema de justiça criminal visualiza todas as vítimas da mesma maneira, não possuindo estrutura para lidar com esses casos que envolvem uma carga subjetiva tão intensa e complexa.

De acordo com Montenegro, essa dupla vitimização fica nítida principalmente nos casos em que ocorre prisão provisória, pois durante à visita ao presídio, as mazelas do sistema penal brasileiro são apresentadas às vítimas, e os estabelecimentos que o compõem, segundo Wacquant:

[...] se parecem mais com campos de concentração para pobres, ou com empresas públicas de depósito industrial dos dejetos sociais, do que com instituições judiciárias servindo para alguma função penalógica - dissuasão, neutralização ou reinserção. $\mathrm{O}$ sistema penitenciário brasileiro acumula, com efeito, as taras das piores jaulas do Terceiro Mundo, mas levada a uma escala

101 MATHIESEN, Thomas. Juicio a la prisón: uma evalución crítica. Trad. Mario Coriolano y Amanda Zamuner. Buenos Aires: Ediar, 2003, p. 209 
digna de primeiro mundo, por sua dimensão e indiferença do político e do público. ${ }^{102 "}$

É nesse momento que a mulher, por vezes, percebe que a violência física e moral que seu companheiro, ex companheiro, pai ou irmão está passando, é maior do que tudo o que ela passou. Inicia-se, assim, um processo interno de culpabilização.

A cena que antecede a audiência, nos casos de réu preso, não pode passar desapercebida: o homem, agressor, algemado, encostado na parede e sendo observado pelo policial militar e demais passantes, como uma pessoa perigosa para o convívio social e, ao seu lado, chorando, está a pessoa que mais deveria ter medo dele, a vítima, pois a prisão provisória geralmente é justificada para preservar a sua integridade física. ${ }^{103}$

A mulher passa, então, a "defender" o agressor durante o processo criminal, e vê-se taxada de mulher que "gosta de apanhar" e que "não sabe o que quer" pelos mesmos operadores do direito que prometeram protegê-la, configurando uma verdadeira violência institucional. Soma-se a isso o fato de ela não só ter sua renda diminuída com a prisão do companheiro, como também um aumento nas despesas, pois vai visitá-lo, juntamente com os filhos, e ainda precisa levar toda sorte de mantimentos para que ele possa sobreviver dentro do sistema.

Como a prisão não ressocializa, apenas piora o indivíduo que lá entra, o homem sai de lá ainda mais violento, e muitas vezes volta para seu lar, onde encontra a mulher ainda mais vulnerável pelo sentimento de culpa. É possível que o ciclo de violência se reinicie, mas dessa vez com a total descrença da mulher no sistema de justiça, o que contribuirá não só para o seu próprio silenciamento, como também para o silenciamento de outras mulheres, que não terão porquê confiar nesse sistema que se mostra incapaz de frear a violência vivenciada.

Cabe ressaltar que casos como esse acontecem majoritariamente quando as partes pertencem às classes sociais mais baixas, uma vez que existe a possibilidade do pagamento de fiança. Assim, quando o agressor pertence à classe média ele pode

\footnotetext{
${ }^{102}$ WACQUANT, Loic. As prisões da miséria. Trad. André Telles. Rio de Janeiro: Jorge Zahar Editor, 2001, p.11.

${ }^{103}$ MONTENEGRO, Marília. Op. cit. p 176.
} 
responder em liberdade, demonstrando-se mais uma vez as pretensões do poder punitivo em reproduzir as desigualdades já presentes na sociedade. ${ }^{104}$

Um outro dado que apareceu na pesquisa é que as mulheres das classes sociais menos favorecidas, em geral, levam os fatos à delegacia não para verem seu companheiro preso, mas para terem acesso ao Poder Público. Muitas vezes, a mulher quer terminar o relacionamento e não sabe como dividir os bens, receber pensão alimentícia e, principalmente tirar o marido de casa. Assim, ela vai à delegacia na esperança de ser auxiliada na solução do problema.

A procura pela polícia revela a total falta de alternativa para a resolução do conflito. Sem ter acesso a outras instâncias que poderiam ajudar a resolver ou até mesmo evitar os conflitos conjugais, resta à mulher procurar a delegacia e, consequentemente, a justiça criminal.

$\mathrm{Na}$ maioria dos casos narrados na pesquisa, a "pena" desejada pela vítima ao seu agressor era apenas a separação e que cada um pudesse viver sua vida dali para frente. O Direito penal, porém, mostra-se mais interessado em servir à própria lógica, só sendo capaz de encontrar um culpado e condená-lo ao cárcere, independentemente da vontade da vítima.

Verifica-se, assim, uma tendência do sistema de justiça criminal em desrespeitar a autonomia da mulher, cujos interesses passam a ser tutelados pelo Estado ainda que contra a sua vontade, e supostamente em nome da sua proteção. Aportando ao sistema, desde o encaminhamento à autoridade policial até o término da instrução e julgamento, a mulher é literalmente deixada de lado, na medida em que o Estado considera ser ela incapaz de decidir por si mesma o que é melhor para sua vida.

Nesse sentido, Vera Andrade sustenta que o sistema penal, que promete proteger a mulher contra o domínio e a opressão das relações sociais que a violentam

${ }^{104}$ MONTENEGRO, Marília. Op. cit. p 251 
e discriminam, acaba se configurando em uma mera continuação desse controle do qual ela tenta se libertar. ${ }^{105}$

Como ressalta Maria Lúcia Karam ${ }^{106}$,

É preciso buscar instrumentos mais eficazes e menos nocivos do que o fácil, simplista e meramente simbólico apelo à intervenção do sistema penal, que, além de não realizar suas funções explícitas de proteção de bens jurídicos e evitação de condutas danosas, além de não solucionar conflitos, ainda produz, paralelamente à injustiça decorrente da seletividade inerente à sua operacionalidade, um grande volume de sofrimento e de dor, estigmatizando, privando da liberdade e alimentando diversas formas de violência.

A solução principal para minorar os conflitos de gênero são as ações de prevenção e educação, além da busca pelo diálogo que capacite homens e mulheres a mudarem de fato a sua mentalidade e os seus comportamentos, e isso passa bem longe do Direito Penal, por tudo o que foi demonstrado ao longo deste trabalho. Muitos passos já foram dados pelas mulheres na luta por sua emancipação e é surpreendente a mudança do papel da mulher do século XIX para o século XXI. O Direito Penal, porém, não fez parte dessa trajetória de conquistas; muito pelo contrário, ele sempre foi utilizado para reprimi-la.

Como adverte Vera Andrade, essa demanda pelo sistema penal acaba por reunir o movimento de mulheres, que é um dos movimentos mais progressistas do país, com um dos movimentos mais conservadores e reacionários, que é o movimento da "Lei e Ordem". "Ambos acabam paradoxalmente unidos por um elo, que é mais repressão, mais castigo, mais punição e, com isso, fortalecem as fileiras da panacéia geral que vivemos hoje em matéria de Política Criminal."107

\footnotetext{
105 ANDRADE, Vera Regina Pereira de. Da mulher como vítima à mulher como sujeito. In: CAMPOS, Carmen Hein de (org). Criminologia e Feminismo. Porto Alegre: Editora Sulina, 1999. P. 111

${ }^{106}$ KARAM, Maria Lúcia. Os paradoxais desejos punitivos de ativistas e movimentos feministas. In: Forum.2015. Disponível em: < https://www.revistaforum.com.br/maria-lucia-karam-os-paradoxaisdesejos-punitivos-de-ativistas-e-movimentos-feministas $>$

107 ANDRADE, Vera Regina Pereira de. Criminologia e feminismo: da mulher como vítima à mulher como sujeito de construção da cidadania. Florianópolis: Sequência. 1997, p. 112
} 
É preciso ter em mente que redimensionar um problema privado e reconstruílo como um problema social, não significa que o melhor meio de responder a ele seja convertê-lo, quase que automaticamente, em um problema penal.

Não será através da criminalização, muito menos da penalização forçada dos homens, aqui os maridos, os companheiros, os filhos, os irmãos, que se terá a resolução de um problema tão arraigado no inconsciente coletivo brasileiro quanto o da busca do papel da mulher na sociedade.

Legitimar esse sistema, essencialmente seletivo, patriarcal e machista, pela ilusão de que ele pode ser mobilizado para a emancipação feminina produz um desvio de esforços do feminismo, que deveria ser dirigido a soluções mais criativas, radicais e eficazes do que utilização desse ramo do Direito nitidamente opressor. 


\section{CONCLUSÃO}

A criação de uma lei que tratasse especificamente da violência doméstica contra as mulheres foi uma grande conquista do movimento feminista, na medida em que, simbolicamente, representou o reconhecimento estatal de que esse fenômeno é um problema social, merecedor de uma especial atenção dos entes públicos.

Porém, reconhecer que o Estado deve intervir não significa dizer que essa intervenção deve acontecer, necessariamente, por meio do sistema de justiça criminal. Existem outros instrumentos muito mais eficazes e transformativos do que o Direito Penal.

A grande questão é que a criminalização aparece sempre como a solução mágica para todos os conflitos, principalmente por parte da mídia, que pressiona e incentiva seus telespectadores a também pressionarem o Estado a endurecer a punição penal de condutas socialmente inaceitáveis.

Atendendo às demandas populares e aproveitando-se da sensação de insegurança generalizada, aqueles que estão no poder criam leis com grande rigor punitivo para agradar seu eleitorado e, ao mesmo tempo, manter intacta a estrutura social desigual que os favorecem, silenciando os debates e reflexões acerca das verdadeiras causas dos conflitos sociais.

No caso da violência doméstica, a raiz do problema está na discriminação de gênero. Trata-se de um problema estrutural. O machismo se mostra presente em todos os grupos, pessoas e instituições em maior ou menor medida, pois fomos educados com discursos machistas e ensinados a reproduzi-los. Qualquer estratégia de luta das mulheres, para ser efetiva, precisa levar isso em consideração.

Apesar de legítima a demanda feminina por um maior rigor penal contra seus agressores, em razão de todo o histórico de opressão, invisibilidade e impunidade contra o quais tiveram que lutar, é necessário perceber que o Direito Penal, salvo em situações excepcionais, não só é um meio ineficaz para a proteção das mulheres contra a violência, como também duplica a violência exercida contra elas, na medida 
em que ele é excludente, seletivo e machista, reproduzindo uma verdadeira violência institucional que recai sobre as próprias vítimas ao não escutar os seus distintos interesses. $^{108}$

Os conflitos envolvendo violência doméstica possuem uma carga de subjetividade que o Direito Penal não é capaz de resolver. A mulher envolvida nessa violência, na grande maioria das vezes, não pretende ver seu agressor preso, seja por acreditar que a prisão não irá resolver nada, seja por ser dependente financeira ou emocionalmente dele, seja por ainda possuir um vínculo afetivo com o mesmo.

Pode-se argumentar que é possível mudar isso, aplicando-se o Direito Penal de forma a respeitar a autonomia da mulher e a ouvir sua voz, seus desejos e necessidades. Isso, porém, parece muito improvável, uma vez que este ramo do Direito sempre encontrou alguma forma de oprimir as mulheres e manter a estrutura patriarcal, sendo difícil acreditar que agora ele poderia ser utilizado para libertá-las. Apostar nele como principal instrumento para a emancipação feminina parece ser uma estratégia extremamente perigosa, por isso o recurso ao sistema de justiça criminal deve ser sempre a última opção.

Diante dessas considerações, conclui-se que se faz muito necessário o empoderamento da mulher, a fim de que ela encontre estratégias próprias para romper o ciclo de violência doméstica. Esse empoderamento pode vir tanto através do tratamento psicossocial dessa mulher para que ela entenda que merece mais do que o relacionamento abusivo que está vivendo, quanto através de sua independência financeira, o que demonstra a necessidade do Estado de oferecer cursos profissionalizantes para as vítimas de violência.

O tratamento psicossocial dos filhos também se mostra primordial, na medida em estes, quando presenciam os episódios de violência enfrentados por sua mãe, podem apresentar marcas e traumas que os acompanharão por toda uma vida, tendo grandes chances, inclusive, de reproduzir o mesmo comportamento no futuro.

\footnotetext{
${ }^{108}$ ANDRADE, Vera Regina Pereira de. Da mulher como vítima à mulher como sujeito. In: CAMPOS, Carmen Hein de (org). Criminologia e Feminismo. Porto Alegre: Editora Sulina, 1999. P. 111
} 
No mais, ressalta-se que a prisão não ressocializa o agressor de violência doméstica ao mantê-lo no cárcere. A prática da violência por ser consequência de comportamentos e ideologias culturais machistas e patriarcais, ou ainda, por se tratar de traços psicológicos do próprio indivíduo, faz com que este torne a reproduzi-la quando não no mesmo relacionamento, em outros que vier a ter. Assim, o tratamento multidisciplinar do homem agressor também se mostra um passo primordial para o enfrentamento da violência doméstica.

A Lei Maria da Penha oferece todos esses instrumentos e mais outros diversos, como a determinação das escolas destacarem a igualdade de gênero nos seus currículos, em todos os níveis de ensino. Se implementados, poderiam gerar efeitos realmente transformadores, uma vez que atuar diretamente nas causas é muito mais efetivo do que atuar apenas nas consequências dos conflitos.

Enquanto os investimentos em políticas públicas e a valorização das medidas disponíveis estiverem direcionadas apenas ao Direito Penal não haverá uma verdadeira coibição da violência doméstica. Já passou da hora de se reconhecer que esse instituto jurídico tão opressor não pode liderar um movimento tão progressista e libertador quanto o movimento das mulheres. 


\section{BIBLIOGRAFIA}

ANDRADE, Luciana Vieira Rubim; ALMEIDA, Marlise Miriam de Matos. Criminalização Da Violência Contra As Mulheres No Brasil: De "Legítima

Defesa Da Honra" À Violação Dos Direitos Humanos. In: Revista Socais \& Humanas CCSH/UFSM, 2017.

ANDRADE, Vera Regina Pereira de. A Soberania Patriarcal: O Sistema de Justiça Criminal no Tratamento da Violência Sexual Contra a Mulher. In: Doutrina Brasiliera, 2009.

ANDRADE, Vera Regina Pereira de. Criminologia e feminismo: da mulher como vítima à mulher como sujeito de construção da cidadania. Florianópolis: Sequência. 1997.

ANDRADE, Vera Regina Pereira de. Da mulher como vítima à mulher como sujeito. In: CAMPOS, Carmen Hein de (org). Criminologia e Feminismo. Porto Alegre: Editora Sulina, 1999.

ANDRADE, Vera Regina Pereira de. Do paradigma etiológico ao paradigma da reação social: mudança e permanência de paradigmas criminológicos na ciência e no senso comum. Florianópolis: Sequência. 1995.

ARDAILLON, Danielle; DEBERT, Guita Grin. Quando a vítima é mulher: análise de julgamentos de crimes de estupro, espancamento e homicídio. Brasília: Conselho Nacional dos Direitos da Mulher, 1987.

BARATTA, Alessandro. Criminologia crítica y crítica del Derecho penal: introducción a la Sociologia jurídicopenal. Tradução por Alvaro Bunster. México: Siglo veintiuno, 1999. 
BATISTA, Nilo. Mídia e sistema penal no capitalismo tardio. Discursos Sediciosos: crime, direito e sociedade. Rio de Janeiro, ano 7, nº12, 2002.

BATISTA, Nilo. Só Carolina não viu - Violência doméstica e políticas criminais no Brasil. In Jornal do Conselho Regional de Psicologia, ano 5, Rio de Janeiro, mar/2008.

BATISTA, Vera Malaguti. Introdução Crítica à Criminologia Brasileira. $2^{\mathrm{a}}$ ed. Rio de Janeiro: Revan, 2011.

BEAUVOIR, Simone de. O Segundo Sexo I: fatos e mitos. São Paulo: Difusão Europeia do Livro, 1970.

BEAUVOIR, Simone de. O Segundo Sexo II: a experiência vivida. São Paulo: Difusão Europeia do Livro, 1967.

BECKER, H. Los extraños. Buenos Aires: Tiempo Contemporáneo, 1971.

BÉO, Cíntia Regina. A sistematização e a hermenêutica como instrumentos garantidores da efetividade dos direitos da mulher na Constituição Federal de 1988. Tese de doutorado apresentada à Faculdade de Direito da Universidade de São Paulo, 2006.

BITENCOURT, Cezar Roberto. Tratado de Direito Penal - parte geral. $13^{\mathrm{a}}$ Edição. São Paulo: Saraiva, 2008.

BOURDIEU, Pierre. A Dominação Masculina. Rio de Janeiro: Bertrand Brasil, 2003.

BUENO, Mariana Guimarães Rocha da Cunha. Feminismo e Direito Penal. Dissertação de Mestrado apresentada na USP. São Paulo: 2011. 
CAMPOS, Carmem Hein de; CARVALHO, Salo. Tensões atuais entre a Criminologia Feminista e a Criminologia Crítica: a Experiência Brasiliera. 2014.

CAMPOS, Carmen Hein de. Disposições preliminares - art. $1 .{ }^{\circ}, 2^{\circ}, 3^{\circ}$ e $44^{\circ}$. In: Campos, Carmen Hein de (org.). Lei Maria da Penha comentada em uma perspectiva jurídico-feminista. Rio de Janeiro: Lumen Juris, 2011.

CAMPOS, Carmen Hein de. Violência Doméstica e Direito Penal Crítico. In: JONAS, Eline. Violências esculpidas. Goiânia: Editora da UCG, 2007.

CAMPOS, Carmen Hein de. Razão e sensibilidade: teoria feminista do direito e Lei Maria da Penha. In: Campos, Carmen Hein de (org.). Lei Maria da Penha comentada em uma perspectiva jurídico-feminista. Rio de Janeiro: Lumen Juris, 2011

CARO, Maria Del Castillo Falcón. Realidad Individual, social y jurídica de la mujer víctima de la violencia de género. In: MORENO, Myriam Herrera (Coord.). Hostigamento y hábitat social: una perspectiva victimológica. Granada: Editorial COMARES, 2008.

CARVALHO, Salo de. Sobre as possibilidades de uma criminologia queer. In: Sistema Penal \& Violência revista do Programa de Pós-Graduação em Ciências Criminais da PUCRS. 2012.

CASTRO, Francisco José Viveiros de. Os delictos contra a honra da mulher: adultério, defloramento, estupro. A sedução no direito civil. Rio de Janeiro, 1897.

COUTO, Maria Cláudia Girotto. Lei Maria da Penha e Princípio da Subsidiariedade. São Paulo. 2016. Dissertação de mestrado defendida na USP. 
COUTO, Sônia Maria de Araújo. Violência Doméstica: uma Nova Intervenção Terapêutica. Belo Horizonte: Autentica, 2005.

DIAS, Maria Berenice. A lei Maria da Penha na justiça. São Paulo: Revista dos Tribunais, 2007.

FACIO, Alda; CAMACHO, Rosália. Em busca das mulheres perdidas: ou uma aproximação crítica à criminologia. In: CLADEM. Mulheres: vigiadas e castigadas. São Paulo, 1995.

FILHO, José Barroso. O perverso ciclo da violência doméstica contra a mulher... Afronta a dignidade de todos nós. Portal do Conselho Nacional de Justiça. Disponível em: <http://www.cnj.jus.br/atos-administrativos/atossecretaria-geral/433-informacoes-para/imprensa/artigos/13325-o-perversociclo-da-violia-domica-contra-a-mulher-afronta-a-dignidade-de-todos-n>.

FRANCHETO, Bruna et al. Antropologia e Feminismo: Perspectivas Antropológicas da Mulher. Rio de Janeiro: Zahar, vol.1, nº 1, 1981.

FREYRE, Gilberto. Sobrados e mucambos - decadência do patriarcado rural e desenvolvimento urbano.In: Intérpretes do Brasil. Rio de Janeiro: Nova Aguillar, 2 ed., 2002.

GREGORI, Maria Filomena. Delegacias de Defesa da Mulher de São Paulo e as instituições: paradoxos e paralelismos. In DEBERT, Guita G.; GREGORI, Maria Filomena; e PISCITELLI, Adriana (orgs.). Gênero e Distribuição da Justiça: as delegacias de defesa da mulher na construção das diferenças. Coleção Encontros. Campinas: Pagu/Unicamp, 2006.

HASSEMER, Winfried. Introdução aos fundamentos do direito penal. Traduzido da $2^{\mathrm{a}}$ edição alemã. Porto Alegre: Sérgio Antonio Fabris Editor, 2005. 
HUNGRIA, Nelson; LACERDA, Romão Cortes de. Comentários ao Código Penal, t. VIII, Rio de Janeiro: Forense, 1947.

JESUS, Damásio de. Direito Penal:parte especial, v. III, 14ª ed., São Paulo: Saraiva, 1999.

KARAM, Maria Lúcia. A esquerda punitiva. In: Empório do Direito. 2015. Disponível em: <http://emporiododireito.com.br/leitura/a-esquerda-punitiva1508702858> último acesso: 28 maio 2018.

KARAM, Maria Lúcia. Direitos Humanos: entre a violência estrutural e a violência penal. Fascículos de ciências penais. Porto Alegre, v. 6, n²2, p. 4461, abr/jun, 1993.

KARAM, Maria Lúcia. Os paradoxais desejos punitivos de ativistas e movimentos feministas. In: Forum.2015. Disponível em: <https://www.revistaforum.com.br/maria-lucia-karam-os-paradoxais-desejospunitivos-de-ativistas-e-movimentos-feministas>

KARAM, Maria Lúcia. Violência de Gênero: o Paradoxal Entusiasmo Pelo Rigor Penal. 2006. In: Boletim do Ibccrim. Disponível em: <https://www.ibccrim.org.br/boletim_editorial/198-168-Novembro-2006> último acesso: 10 maio 2018.

LARRAURI, Elena. Por qué las mujeres maltratadas retiran las denuncias? In: Mujeres y sistema penal:violencia doméstica. Montevideo: B de F Editorial, 2008.

MATHIESEN, Thomas. Juicio a la prisón: uma evalución crítica. Trad. Mario Coriolano y Amanda Zamuner. Buenos Aires: Ediar, 2003.

MENDES, Soraia de Rosa. Criminologia feminista: novos paradigmas. São Paulo: Saraiva. $2^{\text {a }}$ ed. 2017. 
MITCHEL, Juliet. Mulheres: a revolução mais longa. In: Revista Civilização Brasileira, ano III, n. 14, 1967.

MONTENEGRO, Marília. Lei Maria da Penha: uma análise criminológicocrítica. $1^{\mathrm{a}}$ ed. Rio de Janeiro: Revan, 2015.

MORAES, Maurício Zanoide de. "Política Criminal, Constituição e Processo Penal: razões da caminhada brasileira para a institucionalização do caos" in Revista da Faculdade de Direito da Universidade de São Paulo. V. 101, jan-dez 2006.

NORONHA, E. Magalhães, Direito Penal, v. III, 22ª ed., São Paulo: Saraiva, 1995.

NUCCI, Guilherme de Souza. Código Penal comentado. 4. ed., São Paulo: Revista dos TRibunais, 2003.

OLIVEIRA, Ana Sofia Schmidt de. A vítima e o direito penal: uma abordagem do movimento vitimológico e de seu impacto no direito penal. São Paulo: Revista dos Tribunais, 1999.

OLIVEIRA, Lopes de. Criminal injustice: Violence against women in Brazil. Human Rights Watch: New York. 1991.

PIOVESAN, Flávia. Direitos humanos e o direito constitucional internacional. $11^{\mathrm{a}}$ ed. São Paulo: Editora Saraiva, 2010.

PIRES, Thula Rafaela de Oliveira. Criminalização do Racismo: entre política de reconhecimento e meio de legitimação do controle social sobre os negros. $1^{a}$ ed. Brasília: Brado Negro, 2016.

ROXIN, Claus. Estudos de direito penal. Trad. Luís Greco. Rio de Janeiro: Renovar, 2006. 
SAFFIOTI, Heleieth I. B. Já se mete a colher em briga de marido e mulher. In: São Paulo em Perspectiva, São Paulo, v. 13, n. 4, p. 87-88, Dezembro de 1999. Disponível em http://www.scielo.br/scielo.php?script=sci_arttext\&pid=S0102$88391999000400009 \& \operatorname{lng}=e n \& n r m=$ iso. Acesso realizado em 02 de maio de 2018.

SANTOS, Juarez Cirini dos. A criminologia radical. $2^{\mathrm{a} e d .}$ Curitiba: Lumem Iuris: Rio de Janeiro: Forense, 2006.

SCHRAIBER, Lilia. Violência vivida: a dor que não tem nome. Interface Comunicação, Saúde e Educação, Botucatu, v. 7, n. 12, p. 42, fev. 2003. Disponível em: <http://www.scielo.br/scielo.php?script=sci_ arttext\&pid=S1414-32832003000100004\&lng=en\&nrm=iso>.

SECRETARIA DE TRANSPARÊNCIA. Violência Doméstica e Familiar Contra a Mulher. DataSenado, Março de 2013, p. 6. Disponível em http://www.senado.gov.br/noticias/datasenado/pdf/datasenado/DataSenadoPesquisa-Violencia_Domestica_contra_a_Mulher_2013.pdf. Último acesso: 10 maio 2018

SOUZA Eros de; BALDWIN, John R, ROSA Francisco Heitor da. A Construção Social dos Papéis Sexuais Femininos. In: Psicologia: Reflexão e Crítica, 2000.

SUTHERLAND, Edwin Hardin. White Collar Crime. New York: Dryden Press, 1949.

TELES, Maria Amélia de Almeida; MELO, Mônica de. O que é violência contra a mulher. São Paulo: Brasiliense, 2002

WACQUANT, Loic. As prisões da miséria. Trad. André Telles. Rio de Janeiro: Jorge Zahar Editor, 2001. 
WAISELFISZ, Julio Jacobo. Mapa da Violência 2015: homicídio de mulheres no Brasil. Brasília: FRACSO, 2015. Disponível em:<http://www.mapadaviolencia.org.br/pdf2015/MapaViolencia_2015_mulh eres.pdf> Último acesso em 20 maio 2018. 